\title{
Empowering patients and community online: Evaluation of the AIDS community information outreach program
}

\author{
Nicole C. Dancy ${ }^{\mathrm{a}, *}$, Maxine L. Rockoff ${ }^{\mathrm{b}}$, Gale A. Dutcher ${ }^{\mathrm{a}}$, Alla Keselman ${ }^{\mathrm{a}}$, \\ Rebecca Schnall $^{c}$, Elliot R. Siegel ${ }^{\mathrm{d}}$ and Suzanne Bakken ${ }^{\mathrm{b}, \mathrm{c}}$ \\ ${ }^{a}$ Division of Specialized Information Services, National Library of Medicine, Bethesda, MD, USA \\ ${ }^{\mathrm{b}}$ Department of Biomedical Informatics, Columbia University, New York, NY, USA \\ ${ }^{\mathrm{c}}$ School of Nursing, Columbia University, New York, NY, USA \\ ${ }^{\mathrm{d}}$ Elliot Siegel Consulting, Bluffton, SC, USA
}

\begin{abstract}
The AIDS Community Information Outreach Program (ACIOP) was created in 1994 to assist the affected community in utilizing electronic HIV/AIDS information resources. Nearly 300 competitive awards have been made to mostly communitybased organizations. A formal evaluation was undertaken to determine the performance and impact of the ACIOP. A mixed methods design combined quantitative abstractions and summarization of 47 awardee final reports from 44 organizations, and qualitative telephone interviews with 17 individuals representing 20 projects. Findings revealed that project objectives were mostly met; high-risk populations were reached; low resource organizations were funded; community partnerships were significant; projects built on existing efforts; information resources and training were tailored to local needs; and most projects overcame barriers experienced. Needed modifications centered on: (1) enhancing evaluation capacity at the individual project level and (2) revising project reporting requirements to increase the amount of information available to assess the ACIOP; both have been implemented.
\end{abstract}

Keywords: HIV, AIDS, health information, program evaluation, community-based outreach, information dissemination

\section{Introduction}

The National Library of Medicine's (NLM) core mission includes a vigorous outreach program to help assure that its users, including researchers, health professionals, and the lay public, are aware of and make effective use of health information resources available from NLM [18]. This goal is rooted in the conviction that improved heath information access and use provides a foundation for healthier behaviors and outcomes. For the HIV/AIDS community, this explicitly includes patients, their caregivers, and the affected community. The NLM's AIDS Community Information Outreach Program (ACIOP), initiated in 1994, is the principal vehicle for reaching the HIV/AIDS community. A comprehensive evaluation of the ACIOP's performance, impact and continued relevance was conducted by the NLM and Columbia University in 2011-2012. The purpose of this paper is to report on key findings and recommendations from this evaluation.

\footnotetext{
*Corresponding author: Nicole C. Dancy, Two Democracy Plaza, Suite 510, 6707 Democracy Blvd., MSC 5467, Bethesda, MD 20892-5467, USA. Tel.: +1 301496 3599; Fax: +1 301480 3537; E-mail: nicole.scott@nih.gov.
} 
The ACIOP was launched at a critical time in the AIDS epidemic: newly effective but complex multidrug treatments were emerging rapidly but an HIV diagnosis still predicted a shortened life span. At the same time, new information and computer technologies (ICTs) - notably the Internet and the World Wide Web - were also emerging and they foreshadowed a new era in patient empowerment. Patients could now access rapidly the latest authoritative research and treatment information that included complex dosing protocols to which strict adherence was required.

These twin developments were brought together in a landmark conference [10] sponsored and convened by NLM and the NIH Office of AIDS Research (OAR) in 1993. There it became apparent how quickly the HIV/AIDS academic research and clinical communities were embracing the Internet. What was also apparent was the extent to which the affected community, and the organizations and individuals trying to care for them, were similarly motivated to use the new ICTs, but they faced considerable barriers - organizational, financial and logistical. Moreover, while it was clear that many patients and their caregivers were already using the new technologies, many others in the community, particularly members of underserved populations, were unaware of the ICT revolution that was taking place around them [10]. Privacy in seeking AIDS information was paramount, because of the stigma associated with the disease. Internet users, therefore, frequently took advantage of the privacy-protecting computer terminals of a public library that provided free access to the Internet.

NLM initiated the ACIOP in response to the urgent need identified at the 1993 Conference by the HIV/AIDS affected community to reduce the identified barriers to Internet access and a growing wealth of online information resources made available by NLM. This included content from the National Institutes of Health (NIH), Federal Drug Administration (FDA), Centers for Disease Control and Prevention (CDC), the World Health Organization (WHO), national health research and services agencies globally, and leading grass-roots efforts by community-based organizations (CBOs) throughout the US.

The other stakeholders at the Conference - researchers, clinicians and the scientific and public news media - strongly supported the response from NLM to this call to action. That NLM did accept the challenge to help remedy this situation of uneven awareness and use of increasingly important printed and especially newly accessible electronic - HIV/AIDS information resources was recognized as a bold but logical extension of NLM's new focus on outreach [17].

NLM responded first with a policy change that made access to all NLM HIV/AIDS information available to everyone free of charge over the Internet. This marked a significant departure from previous practice in which NLM charged for searching on all of its databases. This change did have a strong impact on underserved populations that previously could not afford access to these resources.

The ACIOP itself was structured to enable CBOs to succeed in competing for small contract awards that did not require the level of staff expertise and supporting infrastructure usually associated with larger organizations skilled in the practice of navigating the traditional award-making process. This was a relatively risky undertaking by a federal agency, but the critical health circumstances of the day and the considerable value of the HIV/AIDS information that NLM had to offer, seemed to justify the risk. Taking this step opened up a funding opportunity to a large number of organizations serving minority and underrepresented groups.

The ACIOP was designed and implemented to allow applicants for funding a relatively wide latitude in the range of projects that could be supported. There were four categories: (1) Improving organizational and community access to electronic HIV/AIDS information (e.g., creating a computer laboratory in a CBO); (2) Providing training to develop information access skills (e.g., holding classes in both Internet use and finding quality information on it); (3) Developing specific educational materials targeting 
local needs (e.g., creating "translations" of new research findings suitable for low-literacy clients); and (4) Providing access to HIV/AIDS-related documents (e.g., inter-library loans, purchasing posters).

Almost 300 projects have been funded in the 19 years since the start of the ACIOP. Awardees have included secular and faith-based CBOs, patient advocacy groups, clinics, public and health sciences libraries, public health departments, and academic institutions working in partnership with community groups.

Several internal evaluations have been performed by NLM over the years that resulted in modest shifts in the ACIOP's emphasis and application procedures. However, in the face of significant changes in information and communication technologies in recent years (e.g., social networking, mobile communications devices) [3,6], along with new HIV/AIDS research findings leading to revised treatment and prevention policies [4], changing demographics [22], etc., along with the prospect of tightened government budgets in coming years, it was deemed appropriate to mount a new and comprehensive evaluation of the ACIOP.

The purpose of the evaluation as defined by NLM was to determine the ACIOP's (1) performance, (2) impact, (3) continued relevance as presently structured given the current status of the epidemic, new tools available, decreasing stigmatization of the disease, and current needs of the affected community, and (4) needed program modifications.

NLM engaged a team from Columbia University with experience in health information outreach and specifically with HIV/AIDS information outreach to develop a suitable evaluation plan and to implement it with a purposive sample of past and current ACIOP awardees. The Columbia team interacted with the NLM/ACIOP team by means of bi-weekly conference calls from the initiation of the engagement and the selection of awards to be included in the study to the development of this paper.

\section{Methods}

\subsection{Evaluation study design}

The mixed methods evaluation design combined (a) quantitative abstraction and summarization of the selected awardee final reports that were scanned by NLM from its archives; and (b) qualitative interviews with principals from the selected projects. Data collection and analysis were informed by the RE-AIM (Reach, Efficacy/Effectiveness, Adoption, Implementation, Maintenance) framework [1,7,8]:

- Reach - the absolute number, proportion and representativeness of participants in a given program (e.g., number of participants in ACIOP project by category).

- Efficacy/Effectiveness - the impact of the program on important outcomes (e.g., ACIOP project goal achievement).

- Adoption - the absolute number, proportion and representativeness of settings willing to offer a program (e.g., number of ACIOP projects led by low resource, community-based organizations).

- Implementation - consistency of delivery of program components and predisposing and enabling factors (e.g., ACIOP projects' technology infrastructure, project management strategies).

- Maintenance - the extent to which a program or policy becomes part of routine organizational practices/policies (e.g., number of ACIOP projects maintained with or without additional resources).

RE-AIM was selected because of its public health perspective and emphasis on looking beyond efficacy/effectiveness to identify other significant findings of relevance to evaluating the ACIOP. Each of the 
RE-AIM dimensions was associated with variable names and data sources that relate specifically to content that could be expected to be found in the awardee final reports and/or in the qualitative interviews. Appendix A contains a comprehensive summary containing all variable names, methods of analysis, and data sources. To align with NLM's specific objectives for the evaluation, the findings were condensed into four overarching evaluation components: (1) performance (Implementation, Maintenance); (2) impact (Reach, Efficacy/Effectiveness, Adoption); (3) relevance to today's needs as structured and (4) needed modifications. Only the first two were informed by the RE-AIM model.

\subsection{Sample}

\subsubsection{Reports}

A Columbia team member purposively selected 47 awardee final reports out of 294 projects to represent the population of awardees in terms of geographical region, type of awardee organization, and type of award (Standard vs. Express). Standard awards are longer in length and receive more funding $(\$ 25 \mathrm{~K}$ to $\$ 60 \mathrm{~K})$ in contrast to Express Awards which are one year in length and receive up to $\$ 10 \mathrm{~K}$. The reports reflected projects funded from 1994-2010 with the majority (70\%) of reports abstracted from the last decade. Two reports were selected for three of 44 awardee organizations to facilitate examination of activities over time from organizations that had received multiple ACIOP awards. Forty reports were from organizations that had received Standard Awards and 7 were from organizations that had received Express Awards.

\subsubsection{Interviews}

The target sample for interviews was individuals from organizations whose awardee final report was selected for inclusion in the report abstraction sample. An ACIOP team member contacted each awardee organization, identified an appropriate individual for interview, assessed the individual's willingness to participate in an interview, gathered contact information, and informed the awardee representative that a member of the Columbia evaluation team would be in contact for interview scheduling. A member of the Columbia evaluation team called or emailed all individuals who agreed to be interviewed. Seventeen individuals representing 20 projects participated in interviews that were recorded, transcribed, and coded. Due to staff turnover for some of the older projects, no one in the organization had sufficient familiarity with the project to be interviewed, but the reports from those projects were included in the quantitative analysis.

\subsection{Evaluation instruments}

\subsubsection{Reports}

Report abstraction variables were initially developed and defined by associating four dimensions of the RE-AIM framework (Reach, Efficacy/Effectiveness, Adoption, Implementation) with the aspects of the ACIOP Awardee Final Report Template that NLM provided to awardees, The Final Report Template changed over the life of the ACIOP; the open-ended questions in the most recent Template are displayed in Table 1. The complete Awardee Final Report Template is in Appendix B and the report abstraction process and variable definitions can be found in Appendix C. For example, Reach addresses the absolute number, proportion, and representativeness of participants in a given project and the ACIOP Awardee Final Report Template has a required table that delineates the primary and secondary direct beneficiaries of the project. As another example, one question related to the Implementation dimension in RE-AIM has to do with ACIOP project components being delivered as intended and the ACIOP Awardee Final 
Table 1

ACIOP awardee final report template open-ended questions

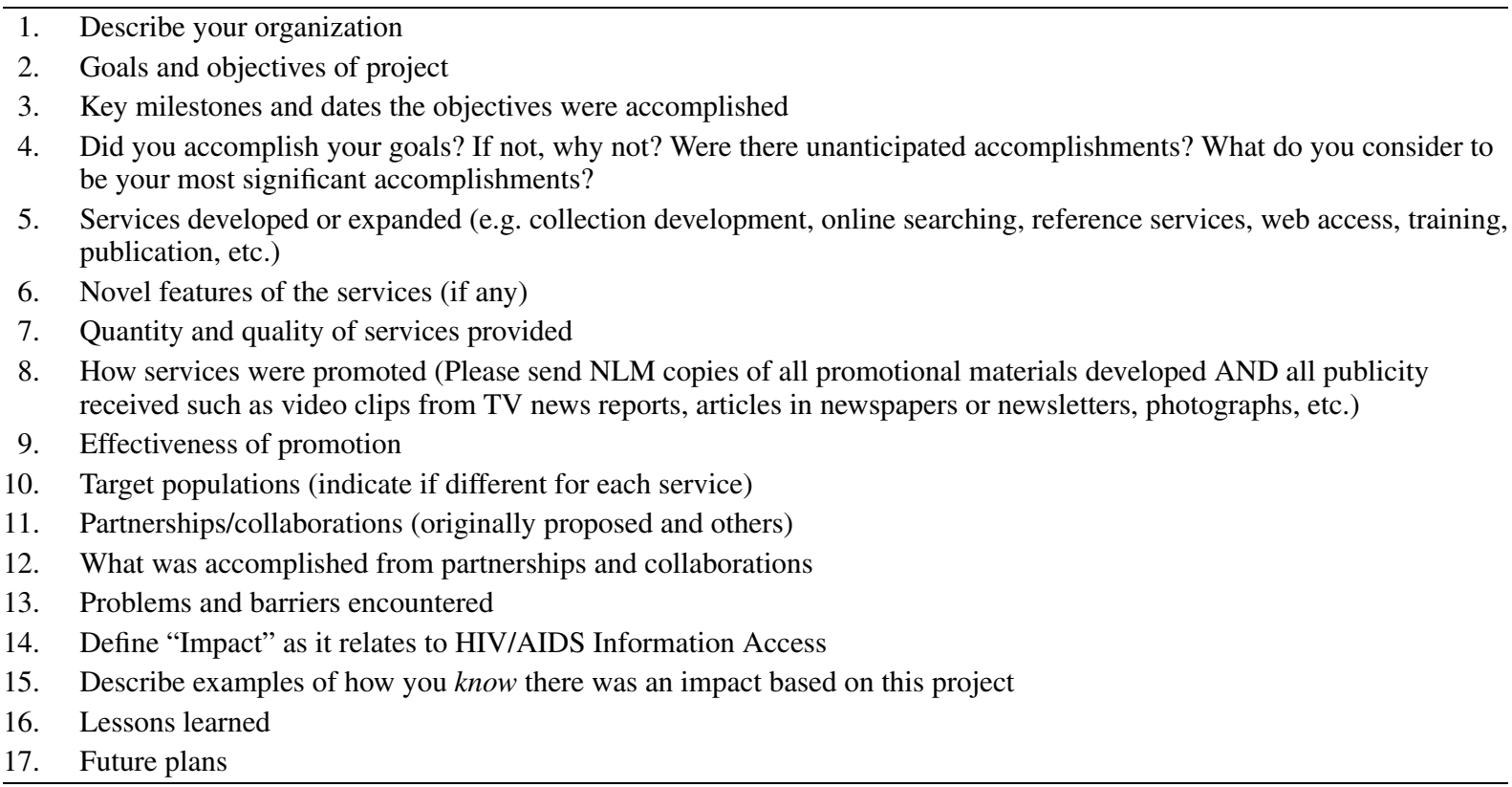

Report Template indicates that awardees should address whether or not their planned objectives were achieved.

\subsubsection{Interviews}

The semi-structured interview guide (Table 2) was developed based upon Efficacy/Effectiveness, Adoption, Implementation and Maintenance dimensions. The heaviest emphasis was on processes associated with Adoption and Implementation to facilitate gathering of insights and lessons learned in regards to barriers and enabling factors that might not be captured in awardee reports. In addition, interviewees were explicitly queried regarding unintended positive and negative consequences of their projects.

\subsection{Data collection procedures}

After familiarization with the abstraction tool (Appendix C) and abstraction of several reports to assess consistency of abstraction, two Columbia team members abstracted variables from the 47 project reports and entered data into the report abstraction database. Two Columbia team members conducted interviews with 17 individuals representing 20 awardees using the semi-structured interview guide. Seventeen interviews were audiorecorded and professionally transcribed to create verbatim transcripts.

\subsection{Data analysis}

The quantitative report abstraction data were summarized with descriptive statistics and organized according to dimensions of the RE-AIM framework.

The development of the initial coding framework for the qualitative interview data started with four of the five RE-AIM dimensions (Efficacy/Effectiveness, Adoption, Implementation, Maintenance). Reach was not included because it is primarily a quantitative assessment that was expected to be found in 
Table 2

Semi-structured interview guide

1. We understand that the primary focus of your project was ... and the target populations were. . .Please share some of your general thoughts about your project (Warm Up Question)

2. How was your project consistent or inconsistent with your organization's mission, values and priorities? (RE-AIM Adoption)

3. How did you implement your ACIOP project (Probes - collaborations, project leadership, management and staffing; marketing)? (RE-AIM Implementation)

4. How did you facilitate the use of the services or resources developed in your project (Probes - marketing, training, coaches)? (RE-AIM Adoption and Implementation [Enabling Factors])

5. What were some of the challenges to use of the services or resources developed in your project (Probes inconvenience, technical, staff turnover)? (RE-AIM Adoption and Implementation [Predisposing Factors])

6. How did you overcome these barriers (Probes related to barriers identified in question 4)? (RE-AIM Adoption and Implementation [Enabling Factors])

7. How did the services or resources you created in your project increase access to HIV information? (RE-AIM Effectiveness)

8. What were some of the unintended positive (i.e., serendipitous) or negative consequences of your project? (RE-AIM Efficacy/Effectiveness)

9. Once the funding for the project was over, how did you continue to support use of your information service or resources? (RE-AIM Maintenance (Reinforcing Factors))

10. Based on your experiences, what would you tell other organizations about what is needed to implement an NLM AIDS Community Information Outreach Project?

11. Are there any other thoughts about your project that you did not get a chance to share that you would like to share now? (Clean Up Question)

the report abstraction process. Twelve of 14 themes associated with the four dimensions were developed from questions associated with the original RE-AIM framework [7,8] or with its extension by Bakken and Ruland [1]. Two themes - Community Involvement and Marketing Strategies - were added to Adoption based upon their relevance to the ACIOP and organizational literature that suggested their importance. Three Columbia team members coded individual awardee interviews. Half of the interviews were reviewed by a second coder to ensure consistent application of the initial coding framework.

After the qualitative interview data were coded into 12 of 14 themes from the initial coding framework, four team members inductively generated 51 categories within the themes (details are available in Appendix D) and coded interview data into 51 categories and three themes that did not have associated categories. Differences were resolved by discussion to achieve consensus.

When both awardee report quantitative abstraction data and awardee qualitative interview data were available for RE-AIM dimensions, the data were triangulated to compare and contrast findings. The triangulated findings were then condensed into four overarching evaluation components in accord with the NLM's areas of interest for the evaluation: (1) performance (Implementation, Maintenance); (2) impact (Reach, Efficacy/Effectiveness, Adoption); (3) relevance and (4) needed modifications in the ACIOP.

\section{Findings}

Key evaluation findings are summarized in the following paragraphs according to Performance, Impact and Relevance. Illustrative interviewee comments are integrated into the findings. Additional examples of interviewee comments for each theme and category are in Appendix E. 


\subsection{Performance}

\subsubsection{Project objectives were achieved (RE-AIM implementation)}

According to awardee reports, more than $75 \%$ of the projects addressed each of first three project categories in the ACIOP solicitation: improving access to electronic HIV/AIDS information, training and skills development, and developing educational materials. Only about one-third focused on accessing HIV/AIDS related documents.

Of 194 planned objectives in the 47 projects, $164(84.5 \%)$ were achieved with no more than minimal variation. Fifteen projects (31.9\%) had one or more objectives that were not achieved as intended. Only one project in the sample did not achieve any objectives. Among the 30 planned objectives that were not achieved, objectives related to evaluation and training were reported most frequently with 9 instances each. Unmet objectives related to development of educational materials were reported 8 times. Other unmet objectives related to improving access to electronic HIV/AIDS information or increasing awareness of HIV/AIDS information.

\subsubsection{Projects built upon existing efforts (RE-AIM implementation)}

Interviewees also identified the importance of building upon existing efforts. For example, an interviewee from a public library whose project focused on HIV outreach and awareness noted that "So we have Healthlink, but we also have a program called the New Americans Program, and we also have our Adult Learning Center. All of them are critical in implementing a program on HIV/AIDS outreach and awareness when you need to put into different languages". Interviewees from CBOs also emphasized this as indicated in a statement from an organization that received multiple ACIOP awards "... .because it layered on existing efforts, we were able to include it in a number of ways" and "The way when we originally wrote the first proposal for the resource room, ... it was a part of our hotline".

\subsubsection{Most projects overcame barriers (RE-AIM implementation)}

Awardee barriers identified were of two types: (1) barriers internal to an awardee's organization, which were the most frequently reported; and (2) barriers external to the awardee, which were typically associated with the target populations served. Barriers were identified in 38 (80.9\%) reports (Table 3). Three categories of awardee barriers occurred in at least one-fourth of reports: changes in staff, technology infrastructure and other which included partnership issues particularly in regards to recruitment of participants. The interview data confirmed awardee barriers identified in reports related to staffing, recruitment, technology infrastructure, budget and project management. The interview data revealed additional barriers including evaluation capacity, lack of expertise in disseminating sensitive information, mismatch between user needs and project approaches, matching resource to clients in crisis, client privacy/confidentiality, and lack of logistical support for client participation. Exemplary quotes from the interviews are displayed in Table 3.

External awardee barriers related to target population (clients, general public, healthcare professionals, library staff) were identified less frequently $(<15 \%)$ than awardee barriers of an organizational nature. With the exception of literacy, they were primarily described in reports rather than interviews. Literacy issues such as functional literacy and computer literacy were identified for clients (14.3\%) and the general public $(4.1 \%)$ in awardee reports. Interviewees also identified functional literacy as a challenge with one individual from an urban mid-western CBO stating " . . and then the other challenge was the literacy level of the clients. And so, we had to bring it down a little. And we really have to meet the client where the client's at". Computer literacy was also a challenge. For example, another interviewee stated, "Because a lot of them are not computer savvy, they're not familiar with computers, we have to show them how to do that". 
Table 3

Organizational barriers Identified in Reports and awardee Interviews

\begin{tabular}{llc}
\hline Type of barrier & Reports $N(\%)$ & Interviews
\end{tabular}

\section{Identified in Reports and Interviews}

Other (e.g., recruitment, retention, changes in partnering organization that affected primary organization's ability to achieve objectives)

Staff change/turnover

Technology

infrastructure

Inadequate staff

Inadequate budget

$9(18.4 \%)$
- "Well, I think one of the earlier challenges was actually recruiting people to come to workshops ... But now that we really invite organizations, it's a little bit more stable". (Standard Award Inner City Academic Institution)

- "... people were interested but to get them to take that next step to call in, to listen to our webinars, all of that, really, I found to be one of the major challenges". (Standard Award Urban CBO)

- "the clinic's budget was cut, so we didn't have as many physicians seeing patients during the course of the project (which affected number of patients who could be recruited)". (Standard Award Urban Academic Institution)

- "Staff turnover is a huge issue. Sometimes it's literally people moving between organizations, but I do think that it's high burnout working in this field and so people come and may stay for a few years and look for other work". (Standard Award Inner City CBO)

- "Here in Kentucky we had turnover among the social work staff. And as I said, they lost two internal medicine physicians and one infectious disease doc position during the course of the project". (Standard Award Academic Institution)

$13(26.5 \%) \quad$ “. . . the biggest challenge is you're all set, you're ready to go, you've got everything lined up you go to do a training and the power goes out". (Standard Award CBO serving urban and rural constituencies)

"Computer technology availability, so you can't - at least you couldn't then get into Second Life on just any low-end computer". (Standard Award Library serving urban, suburban, and rural constituencies) (Note: "Second Life" is an online virtual world.)

"And then, you know definitely challenges with like equipment working and like some organizations blocked YouTube or they blocked PDFs. And you know it's always like trying to get the IT people to come in and really pay attention. And we've had maybe three computers stolen over the years. Yes, but you know, now we lock them down so hard, we can hardly remove them when they need to be repaired". (Standard Award Inner City Academic Institution)

- "So, I think some of our challenge is that while we have created this access, it's fairly limited because we're only able to staff it three days a week. We don't yet have late evening or weekend time. So that's a challenge. And most of that is simply around being able to fund the human resources and the time we need for that". (Standard Award Urban CBO)

- "But going out to do, even though the community, for example, even you know going out to the community and doing the HIV training for our daycares was good, it took me away from the center. And I wasn't able to be here with the clients". (Standard Award Urban CBO)

- "I don't think it's realistic to be able to manage and implement a program, certainly if it's new, with $\$ 60,000 "$ ". (Standard Award Inner City Academic Institution)

- "I mean we don't have the capacity to probably do as much as we could, or as much as people would want us to do. And so that's one reason we don't really market that extensively". (Standard Award Inner City Academic Institution) 
Table 3

(Continued)

\begin{tabular}{|c|c|}
\hline Reports $N(\%)$ & Interviews \\
\hline \multicolumn{2}{|l|}{ Identified in Interviews Only } \\
\hline $\begin{array}{l}\text { Inadequate project } \\
\text { management }\end{array}$ & $\begin{array}{l}\text { - "So I think the management side of things is always the more challenging. } \\
\text { It's a lot of effort organizing any kind of program ... you know that ... then } \\
\text { just trying to keep momentum going". (Express Award Inner City CBO) }\end{array}$ \\
\hline & $\begin{array}{l}\text { - "You know, you just get it going. You find out you got funded, you get it } \\
\text { going, and then you're actually going to have, I think, a smaller window to do } \\
\text { the work and allow for any contingencies". (Standard Award CBO serving } \\
\text { urban and rural constituencies) }\end{array}$ \\
\hline
\end{tabular}

Lack of evaluation capacity

Lack of expertise in disseminating sensitive information

Mismatch between user needs and project approach

Matching resource to clients in crisis
- "I think another challenge in all of these projects is the evaluation piece, which is what you're grappling with also, like what are the outcomes that are realistic and pertinent to NLM. We have here a lot of different outcomes we'd like to see and they're hard to measure". (Express Award Inner City CBO) - "So, I mean the weakness of our work, and I'm sure it's hard for everybody, is ... and my mostly focus is on trainings, is once you have a workshop or a discussion and if you don't see the people again, you don't really know how they're using the information". (Standard Award Inner City Academic Institution)

- "we had to try to figure out a way in which to really talk about the issue without scaring people. ... it really was more of an issue of how do we even promote the fact that we're offering these workshops and offering the materials in the library setting around HIV and AIDS. So it was a ... we needed a whole different type of professional and a whole different type of community coordination around that". (Express Award Urban Public Library) - "I don't think we were honestly organizationally at that point very adept at creating accessible tools for survivors themselves, just the language we would use, the amount of detail. You know our ability to translate what we knew to something that was useful to survivors was limited at that time. And we were, I mean I still think it's a struggle, but we're much more aware of the kinds of things we would need to think about before we would put out something that was sort of public than we used to be". (Standard Award Inner City CBO)

- "We didn't think the camaraderie and the soft skills would be so critical. So, the initial issues was with our IT staff, you know, because they're very IT. . . we realized quickly that they were not the people to be providing technical support to members. That just wasn't their skills ... So, that was one challenge, but once we pulled that back and really got the staff from the hotline, and then also the AmeriCorps people in place, they addressed that pretty quickly". (Express Award Urban Public Library)

- "They're calling things up on their phone. They're not at their computer often. You know when they're searching for information; it's from a handheld in their office and so on and so forth". (Express Award Urban CBO)

- "And the other thing is that people's lives are such that trying to do something on a scheduled basis was somewhat of a challenge. You know the telephone conferences were actually at a set time on a set day". (Standard Award Urban CBO)

- "And we serve people who, you know, it's only been a couple of hours since they were assaulted to people who were assaulted thirty years ago and maybe are wondering when their HIV was a result of the rape that they experienced. You know it could be a whole gamut of things, so we have to really narrow the audience for the tool". (Standard Award Inner City CBO) 
Table 3

(Continued)

\begin{tabular}{|c|c|c|}
\hline Type of barrier & Reports $N(\%)$ & Interviews \\
\hline $\begin{array}{l}\text { Client privacy/ } \\
\text { confidentiality }\end{array}$ & & $\begin{array}{l}\text { - "It was our own creation with social network because there were issues } \\
\text { around confidentiality related to using Facebook that we didn't anticipate } \\
\text { initially. And so we created our own social networking page that still is up } \\
\text { and running and it's still active, and John keeps it up-to-date". (Standard } \\
\text { Award Urban CBO) } \\
\text { - "For example, one of the women is a domestic violence survivor. And she } \\
\text { didn't want anything of her face or imagery on the web because she didn't } \\
\text { want her former abuser to be able to find her or to use her pictures, or } \\
\text { anything like that". (Standard Award Inner City CBO) }\end{array}$ \\
\hline $\begin{array}{l}\text { Lack of logistical } \\
\text { support for client } \\
\text { participation }\end{array}$ & & $\begin{array}{l}\text { - "Another challenge is the transportation for the participant and the distance } \\
\text { from where they live. You know, public transportation is not really the } \\
\text { greatest, and sometimes they don't have time". (Standard Award Urban CBO) } \\
\text { - "We work with Latinas, and most of them are housewives or single parents, } \\
\text { no income. I'm exploring the possibility to entertain their kids so they will } \\
\text { have more time for them to practice all the computer skills, and learn more, } \\
\text { and so on and so forth". (Standard Award Urban CBO) }\end{array}$ \\
\hline
\end{tabular}

Most projects overcame barriers and $46 \%$ of awardee final reports described some type of enabling factor. These included technology infrastructure (21\%), marketing strategies (19\%), organizational commitment (17\%), budget (17\%), staffing (17\%), leadership (8\%) and project management (18\%). Interview data confirmed the importance of the enabling factors reported. Eleven additional categories of enabling factors were discussed in awardee interviews. In terms of project development and implementation, these included: needs assessment, pre-submission planning, use of NLM resources, partnerships (with organizations at the front line), build on existing organizational efforts, engage expertise, and plan for evolving technologies. Three factors were specific to clients - creating a safe environment, tailoring resources to user needs, and providing logistical support for participation. Consideration of the context in which the project work is placed was only mentioned by a few interviewees.

\subsubsection{Project sustainability varied (RE-AIM maintenance)}

Several patterns emerged among the interviewees who addressed sustaining of their NLM project. Projects were categorized as "maintained with existing resources" if the project funding resulted in the creation of resources that had a life beyond the funding period without additional funding. In contrast, projects that secured additional resources from NLM or elsewhere to build upon the existing project were categorized as "maintained with new resources". Projects that maintained relationships but not activities associated with the NLM award were labeled "maintained relationships". If the interviewee indicated that the project activities or resources were not maintained, the project was considered "not maintained". Illustrative examples:

- Maintained with existing resources - A CBO interviewee stated "It's one of those programs that because funding ended, the program didn't go away. The program is still as viable, you know, maybe we have more limited resources, but it just has really been a real good addition for our agency's list of resources that we have available for our clients".

- Maintained with new resources - An awardee from a CBO that has received multiple awards emphasized the importance of building upon investments - in their instance, an online educational management system. She said that "I feel like this grant actually was the impetus for a series of other grants that we ended up being able to get both through the National Library of Medicine and 
through some other sources as well because we sort of invested in creating the system in this class so then we could say we have the system in this class and we're ready to go".

- Maintained relationships - In some instances, relationships were maintained even when specific project-funded activities ended. An awardee from an educational institution stated that "We've maintained relationships with many of the libraries, and of course the college has the relationship with the Lutheran Church downtown, so we're able to do some clinics for the clinical clerkships, we're able to do those, and then, the libraries, of course, can contact us...".

- Not maintained - Some awardees did not maintain or seek further funding for project activities either because of difficulty balancing current activities or change in organizational priorities. For example, an interviewee from a CBO noted that "When the project ended, it was decided by the management that we would not continue to search out funding, since it wasn't a priority...".

\subsection{Impact}

Impact was examined from several perspectives taking into account Reach, Adoption and Efficacy/Effectiveness dimensions of the RE-AIM framework.

\subsubsection{Awardees were community-based and community-engaged organizations serving high risk populations (RE-AIM Reach, Adoption)}

The predominant type of organization to lead a project was a CBO (50\%) followed by an academic $(20.5 \%)$. CBO was also the most frequently occurring type of partner organization. Healthcare and academic organizations as well as public libraries and health departments were more likely to be partner organizations than to be lead organizations.

In terms of high-risk populations, the primary and secondary populations served (Table 4) provide strong evidence that the projects focused on high-risk populations including racial and ethnic minorities, substance users, people living with HIV (PLWH), and the lesbian, gay, bisexual and transgender (LGBT)

Table 4

\begin{tabular}{lcc}
\multicolumn{3}{c}{ Populations served $(N=44)$} \\
\hline At risk population $^{1}$ & $N(\%)$ & $N(\%)$ \\
& Primary & Secondary \\
\hline African American & $21(47.7)$ & $21(47.7)$ \\
Alaska native & $2(4.5)$ & $0(0)$ \\
Asian American & $6(13.6)$ & $3(6.8)$ \\
American Indian & $6(13.6)$ & $3(6.8)$ \\
Hawaiian/Pacific Islander & $4(9.1)$ & $2(4.5)$ \\
Hispanic American & $18(40.9)$ & $7(15.9)$ \\
White & $1(2.3)$ & $0(0)$ \\
Youth/Teen & $13(29.5)$ & $7(15.9)$ \\
Senior & $9(20.5)$ & $5(11.4)$ \\
Inner city & $16(36.4)$ & $1(2.3)$ \\
Rural & $8(18.2)$ & $1(2.3)$ \\
PLWH & $29(65.9)$ & $5(11.4)$ \\
LGBT & $16(36.4)$ & $7(15.9)$ \\
Other & $12(27.3)$ & $3(6.8)$ \\
Missing & $3(6.4)$ & $32(65.9)$ \\
\hline
\end{tabular}

${ }^{1}$ Select all that apply. 
populations. In addition, more than half of the awardees reported inner city $(22.7 \%)$ or urban $(31.8 \%)$ as the primary geographical area of focus.

Patients and families were the primary direct beneficiary in more than half of the projects, followed by general public (48.9\%). Health professionals were primary direct beneficiaries in more than one quarter of the projects. All categories were also secondary direct beneficiaries for at least one project among the 16 reporting.

\subsubsection{Difficult to assess impact due to limited evaluation activities reported (RE-AIM Efficacy/Effectiveness)}

Awardees from 2006 onward were asked to describe explicitly the quality and quantity of services provided as well as evidence of impact in their final reports. The type of evaluation for the 20 awardee (14 Standard, 6 Express) final reports for the time period of 2006-2010 is summarized in Table 5.

In terms of quantitative data, most projects simply tabulated the number of offerings and attendees. Five $(25 \%)$ projects measured web site or online resource use. For example, a project that implemented Second Life, an online virtual world, was able to capture the number of avatars (i.e., people) within sensor range. Only two Standard awardees (and no Express awardees) implemented pre- and post-tests of educational offerings to assess changes in factors such as awareness, knowledge, and skills related to NLM resources. A single awardee assessed the relationship between training and behavior and found that the training resulted in youth completing HIV testing at a rate of about 50/month (as compared to none before the training) among high risk individuals who were unlikely to have been previously tested.

In some final reports, awardees reported interviews, informal participant feedback, open-ended surveys, and resource-use-log comments as sources of qualitative data to document impact. Examples of impact described from these sources included: increased awareness of NLM resources, improved computer skills and online information seeking behaviors, change in HIV knowledge, and advancement of advocacy skills. This was often in the form of describing individual clients or peer educators rather than through formal evaluation methods.

Table 5

Type of evaluation $(N=20)$

\begin{tabular}{lcc}
\hline Type of evaluation & $\begin{array}{c}\text { Standard }(N=14) \\
N(\%)\end{array}$ & $\begin{array}{c}\text { Express }(N=6) \\
N(\%)\end{array}$ \\
\hline Quantitative & $10(71.4)$ & $5(83.3)$ \\
Offerings & $9(64.3)$ & $4(66.7)$ \\
Attendees & $4(28.6)$ & $1(16.7)$ \\
Web site/online resource use & $1(7.1)$ & - \\
Course evaluation & $1(7.1)$ & $1(16.7)$ \\
Circulation data & $1(7.1)$ & - \\
Document delivery & $2(14.3)$ & - \\
Pre- and post-training assessments & - & $1(16.7)$ \\
HIV-related behavior & & \\
Narrative & $1(7.1)$ & $1(16.7)$ \\
Interviews & $1(7.1)$ & $1(16.7)$ \\
Informal participant feedback & $1(7.1)$ & $1(16.7)$ \\
Survey open-ended & $1(7.1)$ & - \\
Resource use log comments & $3(21.4)$ & $2(33.3)$ \\
Unspecified method &
\end{tabular}


Although the evaluation efforts documented in the reports were limited, unintended positive consequences, defined as positive outcomes that were not the planned outcomes of a project, were richly described in awardee interviews.

Four categories of unintended positive consequences related to clients: (1) improved knowledge about health in general, (2) improved education and skills beyond those taught in the project, (3) client empowerment (e.g., use of information from web resources in a clinician visit), and (4) social engagement "people feeling like they have a community". Several interviewees also described situations in which access to accurate resources resulted in an individual's intent to change their stigmatizing behavior toward PLWH.

The first of two categories of unintended positive consequence at the organizational level related to changing the traditional role played by libraries and librarians. The second category comprised instances in which components of the project expanded beyond project intent. This included re-use of project infrastructure for other purposes and having locally-developed project resources "go national".

\subsection{Relevance}

The continued relevance of the ACIOP is supported through evidence that documents the need for (a) community involvement, and (b) tailoring of activities related to developing mechanisms for accessing online information, training, and resource development to meet local needs. These are key aspects of relevance that are congruent with the ACIOP's purpose.

\subsubsection{Community involvement and partnerships were significant (RE-AIM Adoption, Implementation)}

Thirty-four organizations explicitly provided information in their awardee final reports on community involvement: partnering with community groups $(54.5 \%)$, use of volunteers $(38.6 \%)$, participatory client involvement (18.2\%), and community advisory board (4.5\%). The importance of community partnerships and going out into the community was reinforced in the qualitative interviews. For example, one interviewee noted "We found that the easiest way, as opposed to trying to bring them first into the library was for us to actually go out to their sites". Another said "... and initially, we also had a partner with a survivor project, which is no longer in existence, but it was an agency that really focused on information for people living with HIV".

\subsubsection{Information resources and training were tailored to local needs (RE-AIM Implementation)}

Awardee final reports described the necessity for tailoring both information resources and associated training to meet local needs. This was reinforced in the awardee interviews. Tailoring took different forms. In some instances, it involved simplifying information available in government resources: "Sometimes the information that the government or some entity puts together is so cumbersome. So we just try to make it plain". Having materials available in appropriate languages such as Spanish was also mentioned. Other interviewees described the importance of personalizing the information with one stating that "... it was a number of personal stories of women who were dealing with HIV and making decisions about going on treatment, the challenges they had adhering treatment and things like that, so it was putting a personal face on HIV so what we did is we wrote easy to read". A keen understanding of the audience to be reached was identified as a prerequisite to these types of tailoring approaches.

\section{Discussion}

Overall, the ACIOP evaluation provides evidence of successful awardee outcomes consistent with the purpose of the program. Fully 85 percent of project objectives were found to have been achieved 
with minimal variation. This high success rate was accomplished despite the numerous barriers encountered. The barriers were both internal to the organization (such as staff turnover) and external (such as those related to the target population served). This is a commendable benchmark that underscores the resourcefulness of the awardees, their efforts to overcome barriers, and their realistic goal setting within the constraints of available resources. It also demonstrates the sound judgment of the NLM reviewers, who were required to fund entities that could best make a difference at the community level even though they might be novices in applying for and carrying out outreach projects with NLM support.

The results of this evaluation have been subjected to an external review for relevance. NLM convened a Workshop in December 2012 that addressed various aspects of the ACIOP and included on the agenda a Columbia study principal who presented a formal summary of the independently-derived evaluation findings. Invited participants included experts in HIV/AIDS clinical services, AIDS research, and a strong contingent of representatives of awardee organizations that actually participated in the evaluation. The Workshop participants uniformly agreed that the findings accurately reflect their own project experiences, and supported the actions NLM intended to take with respect to two lessons learned that emerged in the study: (1) remediating a lack of evaluation capacity at some awardee institutions; and (2) revising the Awardee Final Report Template. Both measures are described below and are expected to strengthen awardees' project planning and documentation of results going forward.

\subsection{Remediating a lack of evaluation capacity}

One of the lessons learned from the evaluation is that the ACIOP should provide additional guidance to awardees regarding program evaluation to improve the quality of the evaluations in awardee reports. This guidance could take different forms such as establishing minimal technical requirements for project evaluation including evidence of evaluation capacity, providing sample evaluation plans, providing technical assistance on evaluation, establishing a peer-to-peer mechanism for sharing of evaluation materials, and facilitating access to web-based resources for evaluation such as utilization tracking, satisfaction surveys, and skills assessments. The current requirements for award recipients have been changed in response to these recommendations.

Community-based organizations focused on HIV/AIDS have had an important role in the dissemination of HIV prevention materials and tools, including HIV testing services [20,21], and information on HIV prevention activities [14]. Moreover, several leading HIV/AIDS-focused CBOs have developed new knowledge that addresses emerging issues encountered in their practices with clients that could be of value to other CBOs and to policy makers [5]. It is therefore fitting that the NLM initially targeted and to this day continues to emphasize the importance and relevance of CBOs as key beneficiaries of ACIOP funding support.

However, CBOs are often thinly staffed, and their range of technical expertise can be quite limited. This was identified by several project telephone interviewees as a barrier to achieving and successfully documenting project outcomes and impact. Other evidence for this issue is the fact that more than $25 \%$ of the objectives that were reported as not achieved in the awardee reports related to evaluation. It was also independently observed by the Columbia team as a likely cause of missing information in the Awardee Final Report Template (Appendix B) that was the source of the data elements necessary for populating cells in the Report Abstraction Tool (Appendix C). This absence of quantitative data was most keenly felt when reporting on project efficacy and effectiveness.

When an ACIOP project includes a partnership between a CBO and an academic health sciences library, for example, it may be found that this limitation - a lack of evaluation capacity - is substantially 
lessened. In other circumstances, however, it is desirable that NLM explore means that include providing evaluation assistance to awardees that is commensurate with project objectives and the available infrastructure that is proposed in the application to carry out the project. In so doing, it is also important to avoid unnecessarily increasing the sophistication, complexity and cost of a project that is proposed for funding in order to produce evaluation data that, while potentially valuable, exceed the scope and capability of the awardee's staff to carry out the functional objectives of the project as envisioned in the proposal. Balance is needed.

A successful strategy for doing this presently exists. In 2000, NLM published Measuring the Difference: Guide to Planning and Evaluating Health Information Outreach [2]. It was developed in collaboration with the staff of the Pacific Northwest Region of NLM's National Network of Libraries of Medicine $(\mathrm{NN} / \mathrm{LM})$, and was explicitly intended to assist local organizations that lack evaluation expertise and are receiving outreach funding from NLM and the NN/LM. Subsequently, a complementary series of booklets derived from the Guide were produced and include easy-to-understand case studies and worksheets to assist with project planning and evaluation. All materials are available online free of charge from the NN/LM Outreach Evaluation Resource Center (OERC) (http://nnlm.gov/evaluation/guide/). The OERC also offers limited one-on-one expert consultation services that can assist projects desiring additional help.

In response to the need for remediating a lack of evaluation capacity, the 2013 ACIOP solicitation calls for future ACIOP awardees beginning in 2013 to be informed of the availability of the Guide and encouraged to acquire it as a potentially helpful tool that may be used to plan and evaluate their projects. Additionally, a subset of funded projects will also be offered on an experimental basis the opportunity to avail themselves of a technical evaluation expert for one-on-one consultation that is focused specifically on objectives-setting, selecting an appropriate evaluation methodology, guiding the analyses, and interpreting the results. (The administrative costs and effectiveness of NLM offering this assistance will be separately reviewed and evaluated.)

A new webinar will also be developed and offered to awardees that focuses specifically on prospective measures and tools that capture data for a timely assessment of impact within each of the four information access category objectives in the 2013 ACIOP solicitation: information retrieval; skills development; resource development; and a new category - equipment acquisition.

Assessing project impact is especially deserving of enhanced emphasis going forward because it is important for overall management of the ACIOP by NLM, and as an essential feedback mechanism for local projects' own understanding of the effectiveness of their efforts. Sharing information widely and informally amongst ACIOP awardees can also be helpful in generating new insights and identifying commonly encountered evaluation challenges and discussing their potential solutions. All project awardees will be encouraged to avail themselves of a new listserv recently established voluntarily for ACIOP by two current awardees - Philadelphia FIGHT and the Internet Sexuality Information Services (ISIS).

\subsection{Revising the Awardee Final Report Template}

The Awardee Final Report Template (Appendix B) is a critical document and tool for the ACIOP. It is intended to provide a succinct record of a project's activities and accomplishments within a predefined set of categories useful for evaluating both process and outcome. It also serves as a convenient tool for mining data across similar project categories. The template has evolved over the years, and most recently in 2006 introduced the requirement that awardees describe how a project effectively creates awareness 
and makes use of NLM's information resources, both as a destination for answering HIV/AIDS-related questions and as an authoritative and timely resource that can be customized to create targeted information services that are ideally suited to the needs of a local client population.

The present evaluation study has identified several desirable changes to the Awardee Final Report Template, perhaps the most important of which are elaborations on the need for awardees to plan, assess, and report project accomplishments and impact. Accordingly, the 2013 ACIOP award solicitation announcement now includes a requirement that prospective awardees provide evidence of evaluation capacity which may be augmented by means of the new NLM-supported evaluation initiatives described above.

Additionally, the Awardee Final Report Template will now explicitly include sample descriptions of qualitative and, whenever possible, quantitative measurable objectives that are appropriate for each of the four award categories. There will also be the requirement that awardees submit copies of the evaluation tools used and the results achieved that document project impact. For example, projects whose focus is 'Information Retrieval' will be asked to describe specific activities and their frequency associated with creating awareness (e.g., marketing efforts), and means of client use (e.g., desktop vs. mobile devices). Projects seeking to improve 'Skills Development' will report on training (e.g., new user skills acquired, satisfaction with the training experience, knowledge gained) and utilization (e.g., use of new electronic social media, email, mobile, and more traditional printed resources). 'Resource Development' projects will describe specific needs of the target population (e.g., offerings that are more language and/or literacy appropriate), and new local resources that are developed and used (e.g., at project completion, and provisions made to sustain and update them). Projects whose primary focus is 'Equipment Acquisition' will be asked to provide details on the type and quantity of specific hardware and software procured, and/or the utilization of outside technical consultants (e.g., who advise on equipment specifications, or establishment of Internet wi-fi connections) necessary to support efforts to improve access to or the sharing of AIDS-related information.

\subsection{Extending the benefits of internet access and use}

NLM was correct in 1994 to anticipate the emerging importance of access to the Internet and its use in HIV/AIDS prevention, treatment and research. Today, a significant proportion of PLWH - 45\% - turn to the Internet for health information [19]. For these individuals, Internet health information seeking is associated with greater disease knowledge and social support, and active coping strategies [11,12]; higher rates of adherence to antiretroviral therapy [12,19]; and better overall health [12]. The Internet also serves as a valuable source of HIV health information for secondary populations such as HIV negative individuals concerned about sexually transmitted infections [16] and caregivers [9].

Yet research also points to disparities in health information seeking behaviors among PLWH. As is the case with the general population, higher instances of online health information seeking are associated with younger age, higher educational attainment and greater self-efficacy [12,13,19]. A 2006 Pew Internet and American Life Project survey with the general population suggests that despite many programs and initiatives aiming to reduce the digital divide, low-income individuals are still less likely to access and use online heath information [15]. It is reasonable to expect that the divide similarly persists for PLWH. While the scope of the ACIOP is such that it cannot solve all aspects of the digital divide in HIV/AIDS, its initial focus on targeting community-based and community-engaged organizations serving high risk populations as key beneficiaries of ACIOP funding is well placed and achieving success; this focus will continue. Support of projects focusing on improving access to electronic HIV/AIDS information; providing training to develop users' information access skills; developing specific educa- 
tional materials targeting local needs; and assisting community groups with ICT equipment acquisition requirements, all speak to the continued relevance of the ACIOP. They can have real payoff and will continue within the limits of available NLM resources.

\subsection{Potential limitations of the evaluation}

The evaluation findings must be considered in view of potential limitations. First, the sample for the evaluation included only 47 projects from 44 awardees and 17 awardee interviews. Although projects and related interviewees were carefully selected to create a purposive sample representative of geographical regions, type of awardee organization, and type of award (Standard vs. Express), the findings may not be representative of the population of ACIOP awardees. Second, ACIOP reporting requirements have evolved over time and the Awardee Final Report abstraction form was based upon the most recent Awardee Final Report Template. Moreover, based upon the RE-AIM Framework and literature on successful CBOs, the abstraction form also included some data elements explicitly to examine the feasibility of collecting such data. Thus, it was not surprising that some data elements were not present in the majority of reports. Despite these potential limitations, the attendees at the December 2012 ACIOP stakeholder meeting indicated that the evaluation was sufficiently comprehensive and that the findings were representative of their experiences as awardees. Moreover, their consensus was that there was no need for a larger evaluation at this point in time.

\section{Summary and conclusions}

NLM created the ACIOP in 1994, consistent with its outreach mission and in direct response to an urgent request from the affected community for assistance in utilizing HIV/AIDS information resources that increasingly were becoming available via the Internet. Over the course of 19 years, nearly 300 projects were supported by means of relatively small contracts awarded competitively to mostly community-based organizations working alone or in partnership with health science libraries, or other entities.

The evaluation on which this paper is based was undertaken for the purpose of determining the performance and impact of the ACIOP, its continued relevance as presently structured, and to identify any needed modifications. A mixed-methods approach using quantitative analyses of a purposive sample of final project reports, along with qualitative analyses of telephone interviews with selected project leaders, produced the following major findings: (1) awardees' project objectives were mostly met; (2) highrisk populations were reached; (3) low resource organizations were funded; (4) community involvement and partnerships were significant; (5) projects built on existing efforts; (6) information resources were tailored to local needs; and (7) most projects successfully overcame barriers experienced.

The RE-AIM evaluation framework was selected because of its public health emphasis and utility for looking beyond efficacy/effectiveness to identify other significant findings of relevance to the purpose of the evaluation. Ironically, it was with respect to assessing impact that the model fell somewhat short, not due to inherent limitations of the framework, but rather for a lack of uniformly robust measurable data that the individual projects were able to gather and report. In this respect, NLM determined that two key modifications of the ACIOP were in order: (1) enhance evaluation capacity at the individual project level by means of providing awardees with additional tools in the form of guided instruction and one-on-one expert consultation; and (2) revise project reporting requirements to require explicitly both qualitative and quantitative measures of project performance and accomplishment. These programmatic 
changes were implemented by NLM in 2013, and are expected to help ensure that the ACIOP continues to remain relevant and meet its intended purpose of enabling access to up-to-date and authoritative HIV/AIDS information as the epidemic evolves in the U.S. and abroad, new treatment and prevention measures emerge, new information resources are developed and disseminated, and individuals and organizations seek to remain current with advances in health information technology and communications infrastructure.

\section{Acknowledgements}

The program evaluation and preparation of the report were supported by a subcontract under NLM contract HHSN276200900356U with ICF International. The authors thank Dr. Jacqueline Merrill (conceptualization of organizational variables), Ms. Nara Jang (assistance with analysis of awardee reports), Mr. Kenrick Cato (development of database to support analysis of awardee reports), and Ms. Raquel Ramos (assistance with analysis of interviews) for their contributions. The participation of Mr. Cato and Ms. Ramos was supported by T32NR007969 (Reducing Health Disparities Through Informatics, Suzanne Bakken, Principal Investigator). Rebecca Schnall was supported in part by the National Center for Advancing Translational Sciences, National Institutes of Health, through Grant Number KL2 TR000081, formerly the National Center for Research Resources, Grant Number KL2 RR024157.

\section{Appendix A}

An evaluation plan for NLM AIDS community information outreach program.

Methods, variables and data sources by RE-AIM dimensions

\begin{tabular}{|c|c|c|c|}
\hline $\begin{array}{l}\text { RE-AIM } \\
\text { dimension/study } \\
\text { questions }\end{array}$ & Methods & Variable names & Data sources \\
\hline \multicolumn{4}{|c|}{ Reach: The absolute number, proportion, and representativeness of participants in a given program } \\
\hline \multirow[t]{7}{*}{$\begin{array}{l}\text { What percentage of } \\
\text { the primary target } \\
\text { population } \\
\text { participated in } \\
\text { program? }\end{array}$} & $\begin{array}{l}\text { - Retrospective } \\
\text { analysis of past } \\
\text { grantee documents } \\
\text { (final reports, } \\
\text { publications) by four } \\
\text { project categories }\end{array}$ & $\begin{array}{l}\text { - Number of general public participants } \\
\text { - Number of patient and family } \\
\text { participants } \\
\text { - Number of health library participants } \\
\text { - Number of public/other library } \\
\text { participants }\end{array}$ & $\begin{array}{l}\text { Final Report: } 10 \text {, } \\
\text { Target Population } \\
\text { Table - primary direct } \\
\text { beneficiary }\end{array}$ \\
\hline & & $\begin{array}{l}\text { - Number of health professional } \\
\text { participants }\end{array}$ & \\
\hline & & - Number of other participants & \\
\hline & & $\begin{array}{l}\text { - Number of general public eligible for } \\
\text { participation }\end{array}$ & \\
\hline & & $\begin{array}{l}\text { - Number of patient and family eligible } \\
\text { for participation }\end{array}$ & \\
\hline & & $\begin{array}{l}\text { - Number of health libraries eligible for } \\
\text { participation }\end{array}$ & \\
\hline & & $\begin{array}{l}\text { - Number of public/other libraries } \\
\text { eligible for participation }\end{array}$ & \\
\hline
\end{tabular}




\begin{tabular}{|c|c|c|c|}
\hline $\begin{array}{l}\text { RE-AIM } \\
\text { dimension/study } \\
\text { questions }\end{array}$ & Methods & Variable names & Data sources \\
\hline & & $\begin{array}{l}\text { - Number of health professional eligible } \\
\text { for participation }\end{array}$ & \\
\hline & & $\begin{array}{l}\text { - Number of others eligible for } \\
\text { participation }\end{array}$ & \\
\hline & & $\begin{array}{l}\text { - Participation rate - number of } \\
\text { participants from primary target } \\
\text { population(s) (general public, patients } \\
\text { and families, health science libraries, } \\
\text { public/other libraries, health } \\
\text { professionals and other) divided by the } \\
\text { number of eligible for participation in } \\
\text { project (calculated) }\end{array}$ & \\
\hline \multirow[t]{2}{*}{$\begin{array}{l}\text { Were participants } \\
\text { representative of } \\
\text { target population? }\end{array}$} & $\begin{array}{l}\text { - Retrospective } \\
\text { analysis of past } \\
\text { grantee documents } \\
\text { (final reports, } \\
\text { publications) by four } \\
\text { categories }\end{array}$ & $\begin{array}{l}\text { - General public participant } \\
\text { race/ethnicity (fixed response list) } \\
\text { - General public eligible race/ethnicity } \\
\text { (fixed response list) } \\
\text { - Patient and family participant } \\
\text { race/ethnicity (fixed response list) } \\
\text { - Patient and family eligible } \\
\text { race/ethnicity (fixed response list) }\end{array}$ & $\begin{array}{l}\text { Final Report: } 10 \text {, } \\
\text { Target Population } \\
\text { Table - primary direct } \\
\text { beneficiary }\end{array}$ \\
\hline & & $\begin{array}{l}\text { - Representativeness of project } \\
\text { participants (general public, patients and } \\
\text { families) - comparison of participants } \\
\text { and those eligible for participation on } \\
\text { sociodemographic (race/ethnicity, age, } \\
\text { income) characteristics (calculated) }\end{array}$ & \\
\hline \multicolumn{4}{|c|}{ Efficacy: The impact of the program on important outcomes } \\
\hline \multirow[t]{10}{*}{$\begin{array}{l}\text { Did program achieve } \\
\text { outcomes? }\end{array}$} & $\begin{array}{l}\text { Retrospective } \\
\text { analysis of past } \\
\text { grantee documents } \\
\text { (final reports, } \\
\text { publications) by four } \\
\text { project categories }\end{array}$ & $\begin{array}{l}\text { Quality HIV/AIDS Resource Awareness } \\
\text { (numeric) } \\
\text { - General public awareness of quality } \\
\text { HIV/AIDS resources } \\
\text { - Patient and family awareness of quality } \\
\text { HIV/AIDS resources }\end{array}$ & $\begin{array}{l}\text { Final Report: } 2,3,4 \text {, } \\
5,6,7,12,14,15, \\
\text { Target Population } \\
\text { Table - primary direct } \\
\text { beneficiary }\end{array}$ \\
\hline & & $\begin{array}{l}\text { - Health science library awareness of } \\
\text { quality HIV/AIDS resources }\end{array}$ & \\
\hline & & $\begin{array}{l}\text { - Public/other library awareness of } \\
\text { quality HIV/AIDS resources }\end{array}$ & \\
\hline & & $\begin{array}{l}\text { - Health professional awareness of } \\
\text { quality HIV/AIDS resources }\end{array}$ & \\
\hline & & $\begin{array}{l}\text { - Other awareness of quality HIV/AIDS } \\
\text { resources }\end{array}$ & \\
\hline & & $\begin{array}{l}\text { Quality HIV/AIDS Resource Utilization } \\
\text { (numeric) }\end{array}$ & \\
\hline & & $\begin{array}{l}\text { - General public utilization of quality } \\
\text { HIV/AIDS resources }\end{array}$ & \\
\hline & & $\begin{array}{l}\text { - Patient and family utilization of quality } \\
\text { HIV/AIDS resources }\end{array}$ & \\
\hline & & $\begin{array}{l}\text { - Health science library utilization of } \\
\text { quality HIV/AIDS resources }\end{array}$ & \\
\hline & & $\begin{array}{l}\text { - Public/other library utilization of } \\
\text { quality HIV/AIDS resources }\end{array}$ & \\
\hline
\end{tabular}




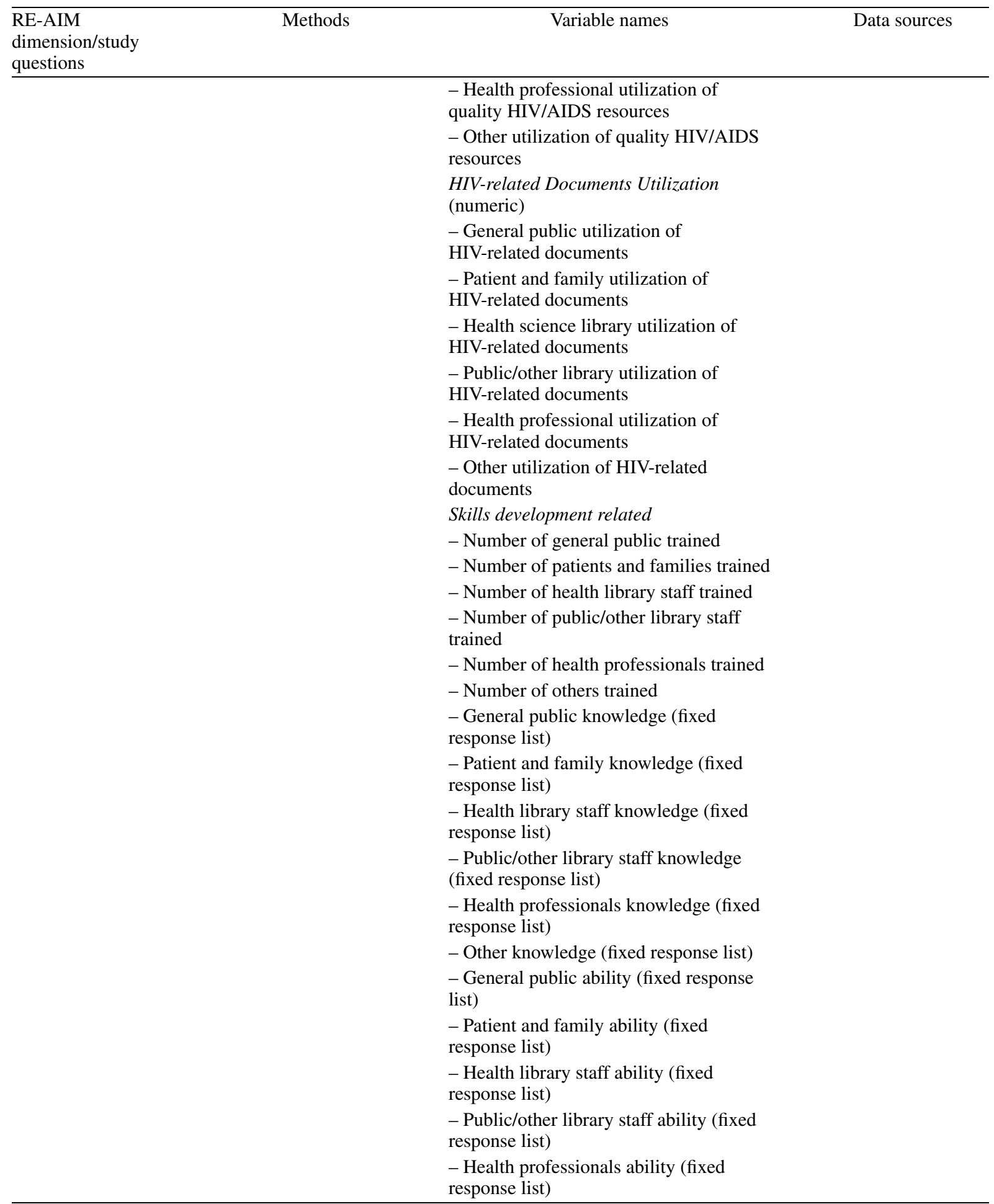




\begin{tabular}{|c|c|c|c|}
\hline $\begin{array}{l}\text { RE-AIM } \\
\text { dimension/study } \\
\text { questions }\end{array}$ & Methods & Variable names & Data sources \\
\hline & & - Other ability (fixed response list) & \\
\hline & & $\begin{array}{l}\text { - General public satisfaction with } \\
\text { training(fixed response list) }\end{array}$ & \\
\hline & & $\begin{array}{l}\text { - Patient and family satisfaction with } \\
\text { training (fixed response list) }\end{array}$ & \\
\hline & & $\begin{array}{l}\text { - Health library staff satisfaction with } \\
\text { training (fixed response list) }\end{array}$ & \\
\hline & & $\begin{array}{l}\text { - Public/other library staff satisfaction } \\
\text { with training (fixed response list) }\end{array}$ & \\
\hline & & $\begin{array}{l}\text { - Health professionals satisfaction with } \\
\text { training (fixed response list) }\end{array}$ & \\
\hline & & $\begin{array}{l}\text { - Other satisfaction with training (fixed } \\
\text { response list) }\end{array}$ & \\
\hline \multirow[t]{2}{*}{$\begin{array}{l}\text { Did it produce } \\
\text { unintended adverse } \\
\text { consequences? }\end{array}$} & $\begin{array}{l}\text { - Retrospective } \\
\text { analysis of past } \\
\text { grantee documents } \\
\text { (final reports, } \\
\text { publications) by four } \\
\text { project categories }\end{array}$ & $\begin{array}{l}\text { - Unintended negative consequences } \\
\text { (text) }\end{array}$ & Final Report: 13 \\
\hline & $\begin{array}{l}\text { - Semi-structured } \\
\text { telephone interviews } \\
\text { with a representative } \\
\text { sample of project } \\
\text { leaders }\end{array}$ & & $\begin{array}{l}\text { Semi-structured } \\
\text { Telephone Interview: } 8\end{array}$ \\
\hline \multirow[t]{2}{*}{$\begin{array}{l}\text { Did it produce } \\
\text { unintended positive } \\
\text { consequences? }\end{array}$} & $\begin{array}{l}\text { - Retrospective } \\
\text { analysis of past } \\
\text { grantee documents } \\
\text { (final reports, } \\
\text { publications) by four } \\
\text { project categories }\end{array}$ & $\begin{array}{l}\text { - Unintended positive consequences } \\
\text { (text) }\end{array}$ & $\begin{array}{l}\text { Final Report: 2, 3, 4, 5, } \\
6,7,12,14,15\end{array}$ \\
\hline & $\begin{array}{l}\text { - Semi-structured } \\
\text { telephone interviews } \\
\text { with a representative } \\
\text { sample of project } \\
\text { leaders }\end{array}$ & & $\begin{array}{l}\text { Semi-structured } \\
\text { Telephone Interview: } 8\end{array}$ \\
\hline \multirow[t]{2}{*}{$\begin{array}{l}\text { What did the program } \\
\text { cost as implemented? }\end{array}$} & $\begin{array}{l}\text { Retrospective } \\
\text { analysis of past } \\
\text { grantee documents } \\
\text { (final reports, } \\
\text { publications) by four }\end{array}$ & $\begin{array}{l}\text { - Number of primary direct beneficiaries } \\
\text { (general public, patients and families, } \\
\text { health science libraries, public/other } \\
\text { libraries, health professionals and other) } \\
\text { (numeric) }\end{array}$ & $\begin{array}{l}\text { Final Report: } 7 \text {, Target } \\
\text { Population Table - } \\
\text { primary direct } \\
\text { beneficiaries }\end{array}$ \\
\hline & $\begin{array}{l}\text { project categories to } \\
\text { examine project costs } \\
\text { and associated } \\
\text { utilization rates or } \\
\text { other primary } \\
\text { outcomes } \\
\text { (cost-consequence } \\
\text { analysis) }\end{array}$ & - Project cost (numeric) & Budget \\
\hline
\end{tabular}




\begin{tabular}{llll}
\hline RE-AIM & Methods & Variable names & Data sources \\
dimension/study & & \\
questions & & \\
\hline
\end{tabular}

Adoption: The absolute number, proportion and representativeness of settings willing to offer a program

Did low-resource organizations serving high-risk populations implement the program?
Did program help the organization address its primary mission?
- Retrospective analysis of past grantee documents (final reports, publications) by four project categories - Review of grantee web site if available

Retrospective analysis of past grantee documents (final reports, publications) by four project categories; Review of grantee web site if available;

Semi-structured telephone interviews with a representative sample of project leaders (past grantees); Prospective data collection for future grantees as part of Organization Profile (See Table 2)
- Name of project

- Name of grantee

- Year awarded

- Purchase order number

- Type of award (standard, express)

- Type of organization (fixed response list)

- Organization mission (text)

- Size: number of employee (numeric), offices (numeric), physical locations (numeric)

- Age: years in operation (numeric)

- Funding sources (fixed response list)

- Resources: physical capital and material goods (text)

- Setting: jurisdictional characteristics (fixed response list), urban/rural (fixed response list)

- Geographical location (fixed response list)

- Functions and services (other than for this project) (fixed response list)

- Management experience (fixed response list)

- Project management strategies used (fixed response list)

- Marketing strategies used (fixed response list)

- Community involvement (fixed response list)

- Influence/prestige of grantee organization (fixed response list)

- Population served (fixed response format)

- Organizational mission (text)

Final Report: 1

Semi-structured

Telephone

Interview: 8
Final Report: 1, 12,

Type of Organization Table; Target

Population Table;

Table - primary direct beneficiaries 


\begin{tabular}{|c|c|c|c|}
\hline $\begin{array}{l}\text { RE-AIM } \\
\text { dimension/study } \\
\text { questions }\end{array}$ & Methods & Variable names & Data sources \\
\hline $\begin{array}{l}\text { Is program consistent } \\
\text { with organizational } \\
\text { values and priorities? }\end{array}$ & $\begin{array}{l}\text { Retrospective past analysis } \\
\text { of grantee documents } \\
\text { (progress and final reports, } \\
\text { publications) by four } \\
\text { project categories; Review } \\
\text { of grantee web site if } \\
\text { available; Semi-structured } \\
\text { telephone interviews with a } \\
\text { representative sample of } \\
\text { project leaders (past } \\
\text { grantees); Prospective data } \\
\text { collection for future } \\
\text { grantees as part of } \\
\text { Organization Profile (See } \\
\text { Table 2) }\end{array}$ & $\begin{array}{l}\text { - Organizational mission (text) } \\
\text { - Functions and services (other than for } \\
\text { this project) (text) }\end{array}$ & $\begin{array}{l}\text { Final Report: } 1 \\
\text { Semi-structured } \\
\text { Telephone Interview: } 8\end{array}$ \\
\hline \multicolumn{4}{|c|}{ Implementation: At the setting level, includes consistency of delivery and predisposing and enabling factors } \\
\hline $\begin{array}{l}\text { What was } \\
\text { developed/done in } \\
\text { project? }\end{array}$ & $\begin{array}{l}\text { - Retrospective analysis of } \\
\text { past grantee documents } \\
\text { (final reports, publications) } \\
\text { by four project categories }\end{array}$ & $\begin{array}{l}\text { - Information access categories } \\
\text { (information retrieval, skills } \\
\text { development, document access, resource } \\
\text { development) } \\
\text { - NLM HIV/AIDS resources utilized } \\
\text { (fixed response list) } \\
\text { - Resources developed (text) } \\
\text { - Trainings developed (text) } \\
\text { - Documents developed (text) }\end{array}$ & $\begin{array}{l}\text { Information Access } \\
\text { Category Table, } 2,3,4 \text {, } \\
9,11,13,16\end{array}$ \\
\hline $\begin{array}{l}\text { Were program } \\
\text { components delivered } \\
\text { as intended? }\end{array}$ & $\begin{array}{l}\text { - Retrospective analysis of } \\
\text { past grantee documents } \\
\text { (final reports, publications) } \\
\text { by four project categories }\end{array}$ & $\begin{array}{l}\text { - Planned project components/objectives } \\
\text { (text) } \\
\text { - Delivered project components/ } \\
\text { objectives (text) } \\
\text { - Difference between planned and } \\
\text { delivered project components (fixed } \\
\text { response format - none, minimal, } \\
\text { moderate, substantial) }\end{array}$ & Final Report: 2, 3, 4 \\
\hline $\begin{array}{l}\text { What barriers to } \\
\text { implementation } \\
\text { (predisposing factors } \\
\text { at individual (target } \\
\text { population) and/or } \\
\text { setting/organizational } \\
\text { levels) were identified } \\
\text { and how were they } \\
\text { addressed? }\end{array}$ & $\begin{array}{l}\text { - Retrospective analysis of } \\
\text { past grantee documents } \\
\text { (final reports, publications) } \\
\text { by four project categories } \\
\text { - Semi-structured } \\
\text { telephone interviews with a } \\
\text { representative sample of } \\
\text { project leaders }\end{array}$ & $\begin{array}{l}\text { - Type of barriers related to target } \\
\text { population of general public (fixed } \\
\text { response list) } \\
\text { - Type of barriers related to target } \\
\text { population of patients and families (fixed } \\
\text { response list) } \\
\text { - Type of barriers related to target } \\
\text { population of healthcare professionals } \\
\text { (fixed response list) } \\
\text { - Type of barriers related to target } \\
\text { population of libraries (fixed response } \\
\text { list) } \\
\text { - Type of grantee barriers: (fixed } \\
\text { response list) }\end{array}$ & $\begin{array}{l}\text { Final Report: } 13 \\
\text { Semi-structured } \\
\text { Telephone Interview: } \\
5,6\end{array}$ \\
\hline
\end{tabular}




\begin{tabular}{|c|c|c|c|}
\hline $\begin{array}{l}\text { RE-AIM } \\
\text { dimension/study } \\
\text { questions }\end{array}$ & Methods & Variable names & Data sources \\
\hline \multirow[t]{2}{*}{$\begin{array}{l}\text { What enabling } \\
\text { (facilitating) factors } \\
\text { were/are required to } \\
\text { support the program? }\end{array}$} & $\begin{array}{l}\text { - Retrospective analysis of } \\
\text { grantee documents by (final } \\
\text { reports, publications) four } \\
\text { project categories }\end{array}$ & $\begin{array}{l}\text { - Types of enabling factors required to } \\
\text { support program (fixed response list) }\end{array}$ & $\begin{array}{l}\text { Final Report: } 9,11,16 \\
\text { Semi-structured } \\
\text { Telephone Interview: } \\
6,10\end{array}$ \\
\hline & $\begin{array}{l}\text { - Semi-structured } \\
\text { telephone interviews with a } \\
\text { representative sample of } \\
\text { project leaders }\end{array}$ & & \\
\hline \multicolumn{4}{|c|}{ Maintenance: The extent to which a program or policy becomes part of the routine organizational practices/policies } \\
\hline \multirow[t]{2}{*}{$\begin{array}{l}\text { Did organization } \\
\text { sustain the program } \\
\text { over time? }\end{array}$} & $\begin{array}{l}\text { - Semi-structured } \\
\text { telephone interviews with a } \\
\text { representative sample of } \\
\text { project leaders }\end{array}$ & - Funded services sustained (text) & $\begin{array}{l}\text { Semi-structured } \\
\text { Telephone Interview: } \\
9,10\end{array}$ \\
\hline & $\begin{array}{l}\text { - Review of grantee web } \\
\text { site if available }\end{array}$ & & Grantee web site \\
\hline $\begin{array}{l}\text { How did the program } \\
\text { evolve? }\end{array}$ & $\begin{array}{l}\text { - Semi-structured } \\
\text { telephone interviews with a } \\
\text { representative sample of } \\
\text { project leaders }\end{array}$ & - Project evolution (text) & $\begin{array}{l}\text { Semi-structured } \\
\text { Telephone Interview: } 9\end{array}$ \\
\hline $\begin{array}{l}\text { What reinforcing } \\
\text { factors were/are } \\
\text { required to maintain } \\
\text { the program? }\end{array}$ & $\begin{array}{l}\text { - Semi-structured } \\
\text { telephone interviews with a } \\
\text { representative sample of } \\
\text { project leaders }\end{array}$ & - Types of reinforcing factors (text) & $\begin{array}{l}\text { Semi-structured } \\
\text { Telephone Interview: } \\
9,10\end{array}$ \\
\hline
\end{tabular}

\section{Appendix B}

HIV/AIDS Community Information Outreach Project

FINAL REPORT

\section{[NAME OF PROJECT] \\ [NAME OF ORGANIZATION] \\ [CONTRACT NUMBER]}

1. Describe your organization

2. Goals and objectives of project

3. Key milestones and dates the objectives were accomplished

4. Did you accomplish your goals? If not, why not? Were there unanticipated accomplishments? What do you consider to be your most significant accomplishments? 
5. Services developed or expanded (e.g. collection development, online searching, reference services, web access, training, publication, etc.)

6. Novel features of the services (if any)

7. Quantity and quality of services provided

8. How services were promoted

(Please send NLM copies of all promotional materials developed AND all publicity received such as video clips from TV news reports, articles in newspapers or newsletters, photographs, etc.)

9. Effectiveness of promotion

10. Target populations (indicate if different for each service)

11. Partnerships/collaborations (originally proposed and others)

12. What was accomplished from partnerships and collaborations

13. Problems and barriers encountered

14. Define "Impact" as it relates to HIV/AIDS Information Access

15. Describe examples of how you know there was an impact based on this project

16. Lessons learned

17. Future plans 
Information access categories

\begin{tabular}{|c|c|c|}
\hline Type of activity & Check if applicable & Comments \\
\hline $\begin{array}{l}\text { Information retrieval } \\
\text { (Internet access, purchase of computer } \\
\text { hardware and software, etc.) }\end{array}$ & & \\
\hline $\begin{array}{l}\text { Skills development } \\
\text { (Training of clients, staff, general public, etc.) }\end{array}$ & & \\
\hline $\begin{array}{l}\text { Document access } \\
\text { (Interlibrary loan, purchase books, etc.) }\end{array}$ & & \\
\hline $\begin{array}{l}\text { Resource development } \\
\text { (Development of fact sheets, brochures, databases, etc.) }\end{array}$ & & \\
\hline
\end{tabular}

Type of organization(s) involved in project

\begin{tabular}{|c|c|c|c|}
\hline Type of organization & Check the lead & $\begin{array}{c}\text { Check if partner } \\
\text { (Check all that apply) }\end{array}$ & $\begin{array}{c}\text { Names of organizations } \\
\text { (Indicate lead) }\end{array}$ \\
\hline \multicolumn{4}{|c|}{ Community organization } \\
\hline \multicolumn{4}{|c|}{ Health sciences library } \\
\hline \multicolumn{4}{|l|}{ Public library } \\
\hline \multicolumn{4}{|l|}{ Other library } \\
\hline \multicolumn{4}{|c|}{ Clinic/other healthcare organization } \\
\hline \multicolumn{4}{|c|}{ Health department } \\
\hline \multicolumn{4}{|l|}{ Hospital } \\
\hline \multicolumn{4}{|l|}{ Faith-based } \\
\hline \multicolumn{4}{|l|}{ Academic } \\
\hline Other - Specify & & & \\
\hline
\end{tabular}

Target populations (Check all that apply)

\begin{tabular}{|c|c|c|}
\hline Direct beneficiaries & Check primary target & Check secondary target(s) \\
\hline \multicolumn{3}{|l|}{ General public } \\
\hline \multicolumn{3}{|l|}{ Patients and families } \\
\hline \multicolumn{3}{|l|}{ Health sciences libraries } \\
\hline \multicolumn{3}{|l|}{ Public/other libraries } \\
\hline \multicolumn{3}{|l|}{ Health professionals: } \\
\hline \multicolumn{3}{|l|}{ - All Types } \\
\hline \multicolumn{3}{|l|}{ - Dentists } \\
\hline \multicolumn{3}{|l|}{ - Nurses } \\
\hline \multicolumn{3}{|l|}{ - Physicians } \\
\hline \multicolumn{3}{|l|}{ - Health Services Researchers } \\
\hline \multicolumn{3}{|l|}{ - Health Professions Students } \\
\hline \multicolumn{3}{|l|}{ - Pharmacists } \\
\hline \multicolumn{3}{|l|}{ - Public Health Workforce } \\
\hline Other - Please specify & & \\
\hline
\end{tabular}




\begin{tabular}{ll}
\hline Populations served & Check primary target \\
\hline African American & \\
Asian American & \\
American Indian & \\
Alaska Native & \\
Hawaiian/Pacific Islander & \\
Hispanic American & \\
Youth/teen & \\
Senior & \\
Rural & \\
Inner city & \\
People living with HIV/AIDS \\
Gay/Lesbian/Bisexual/Transgendered \\
OTHER - Please specify
\end{tabular}

\section{Appendix C. Awardee final report abstraction process and variable definitions}

\section{Process}

Report abstraction variables were initially developed and defined by associating the aspects of the ACIOP awardee final report template (Appendix B) with four dimensions of the RE-AIM framework (Reach, Efficacy/Effectiveness, Adoption, Implementation). For example, Reach addresses the absolute number, proportion, and representativeness of participants in a given program and the ACIO Program Awardee Final Report Template has a required table that delineates the primary and secondary direct beneficiaries of the project. As another example, one question related to the Implementation dimension in RE-AIM has to do with program components being delivered as intended and the ACIO Program Awardee Final Report Template indicates that Awardees should address whether or not their planned objectives were achieved.

Three dimensions, Efficacy/Effectiveness, Adoption and Implementation required substantial expansion beyond the ACIO Program Awardee Final Report Template to operationalize the variables. For Efficacy/Effectiveness, variables were inferred from the four information access categories: Resource Development, Information Retrieval, Skills Development, and Document Access and the ACIO Program goal of improving awareness of resources related to HIV/AIDS resources. Thus, variables were defined for exposure/use of awareness raising activities, resources, documents and skills development training by six categories of primary direct beneficiaries: general public, patients and families, health library staff, public/other library staff, health professionals (including students) and others. In addition, variables with 3-point Likert-type scales were defined to capture changes in awareness and ability for primary direct beneficiaries as a result of participating in awareness raising activities or skills training. Lastly, six training satisfaction variables were created - one for each primary direct beneficiary.

To address the Adoption dimension question of "Did low-resource organizations serving high-risk populations implement the program?", a series of variables from the organizational literature were defined: size, age, funding sources, resources, setting, geographical location, functions and service, management experience, project management strategies, market strategies and community involvement.

In regards to Implementation, variables were defined for categorizing the difference between planned and delivered program objectives and for types of barriers and enabling factors for each category of primary direct beneficiary. 
Variables

- Direct Beneficiary Primary Target (select all that apply): general public, patients and families, health sciences libraries, public/other libraries, health professionals - all, dentists, nurses, physicians, health services researchers, health professions students, pharmacists, public health workforce, other

- Direct Beneficiary Secondary Target (select all that apply): general public, patients and families, health sciences libraries, public/other libraries, health professionals - all, dentists, nurses, physicians, health services researchers, health professions students, pharmacists, public health workforce, other

- Number of general public participants

- Number of patient and family participants

- Number of health library participants

- Number of public/other library participants

- Number of health professional participants

- Number of other participants

- Number of general public eligible for participation

- Number of patient and family eligible for participation

- Number of health libraries eligible for participation

- Number of public/other libraries eligible for participation

- Number of health professional eligible for participation

- Number of others eligible for participation

- Number of not specified eligible for participation

- Participation rate - number of participants from direct beneficiary primary target (general public, patients and families, health science libraries, public/other libraries, health professionals, and other) divided by the number of eligible for participation in program (calculated)

- General public participant race/ethnicity (numbers): African American, Asian American, American Indian, Alaska Native, Hawaiian/Pacific Islander, Hispanic American, White, Other

- Patient and family participant race/ethnicity (numbers in each category): African American, Asian American, American Indian, Alaska Native, Hawaiian/Pacific Islander, Hispanic American, White, Other

- Not specified participant race/ethnicity (numbers in each category): African American, Asian American, American Indian, Alaska Native, Hawaiian/Pacific Islander, Hispanic American, White, Other 


\author{
Variables \\ - Name of project (text) \\ - Name of grantee (text) \\ - Year awarded (4 character numeric) \\ - Purchase order number (13 character numeric) \\ - Type of award (standard, express, not specified) \\ - Type of organization (select all that apply): community organization, health sciences library, public library, other library, \\ clinic/hospital/other healthcare organization, health department, hospital, faith-based, academic, other - specify \\ - Organization mission (text) Note: consistent with stakeholder goals is positive \\ - Size: number of employee (4 character numeric), physical locations ( 1 or $>1)$ \\ - Age: years in operation (numeric) \\ - Funding sources (select all that apply): federal, state, city, foundation, corporate, voluntary agencies, local community groups \\ - Resources: physical capital (total revenues) and material goods (text) \\ - Setting: jurisdictional characteristics (fixed response list): inner city, urban, rural, mixed urban/rural, suburban \\ - Geographical location (fixed response list for state or territory - 56 possibilities): http://www.stateabbreviations.us/ \\ - General functions and services (text boxes - 10) \\ - Management experience (fixed response list) Note-strengthened management is positive: $<2$ years, $2-5$ years, $>5$ years \\ - Project management strategies used (select all that apply) Note: positive if present: defined timeline, task completion \\ tracking, used project management software
}

- Marketing strategies used (select all that apply) Note: variety is positive: brochure/print materials, displays/signs, mailing, emailing, newsletter, phone calls, press release, special events, web site, person-to-person, social media

- Community involvement (select all that apply): use volunteers, partner with community groups, participatory client involvement, community advisory board

- Population Served Primary Target (select all that apply): African American, Asian American, American Indian, Alaska Native, Hawaiian/Pacific Islander, Hispanic American, Youth/Teen, Senior, Rural, Inner City, PLWH, LGBT, Other

- Population Served Secondary Target (select all that apply): African American, Asian American, American Indian, Alaska Native, Hawaiian/Pacific Islander, Hispanic American, Youth/Teen, Senior, Rural, Inner City, PLWH, LGBT, Other 


\begin{abstract}
Project description
- Information access categories (select all that apply): information retrieval, skills development, document access, resource development
\end{abstract}

- Type of Organization Involved Lead (select all that apply): community organization, health sciences library, public library, other library, clinic/other healthcare organization, health department, hospital, faith-based, academic, other

- Type of Organization Involved Partner (select all that apply): community organization, health sciences library, public library, other library, clinic/other healthcare organization, health department, hospital, faith-based, academic, other

- NLM HIV/AIDS resources utilized (AIDSInfo-English, AIDSInfo-Spanish, MedlinePlus-English, MedlinePlus-Spanish, MedlinePlusGoLocal, Medline/PubMed, PubMedCentral, Other, Not specified NLM Resource

- Resources developed (10 pairs of fields - a text field for what and a related target audience field with fixed response list of: general public, patients/families, health library staff, public/other library staff, health professionals, other, not specified

- Trainings developed (10 pairs of fields - a text field for what and a related target audience field with fixed response list of: general public, patients/families, health library staff, public/other library staff, health professionals, other, not specified

- Documents developed (10 pairs of fields - a text field for what and a related target audience field with fixed response list of: general public, patients/families, health library staff, public/other library staff, health professionals, other, not specified

\title{
Project-related processes
}

- Planned program components/objectives (text) (1-many) - Delivered program components/objectives (text) (1-many)

- Difference between planned and delivered program components: none, minimal, moderate, substantial

- Type of barriers related to target population of general public (select all that apply): technology access, literacy, lack of awareness, other

- Type of barriers related to target population of patients and families (select all that apply): technology access, literacy, lack of awareness, incentives for participation, support for participation, other

- Type of barriers related to target population of healthcare professionals (select all that apply): technology access, lack of awareness, time, incentives for participation, other

- Type of barriers related to target population of library staff (select all that apply): technology access, lack of awareness, time, other

- Type of grantee barriers (select all that apply): lack of organizational commitment, change in leadership, inadequate staff, change in staff, technology infrastructure issues, inadequate project management, inadequate marketing, inadequate budget, partnership issues, other

- Types of enabling factors required for grantee to support program (select all that apply): organizational commitment, leadership, staffing, technology infrastructure, project management, marketing strategies, budget, partnerships, other

- Program cost/grant total budget (numeric)

Category of Project-related Outcomes (select all that apply): Awareness, Resource Utilization, Documents Utilization, Skills Development, Satisfaction with Training, Satisfaction with Resource, Satisfaction with Training 
Categories of Methods Used to Measure Project-related Outcomes (select all that apply): Purchases, Installation, Utilization Data, Automated Log Files (e.g., webpage hits), Informal Observations, Formal Observations, Interviews, Critical Incident Technique, Focus Groups, Survey - Pre and Post, Survey Post Only

Quality HIV/AIDS Resource Awareness

- Number of general public aware of quality HIV/AIDS resources

- Number of patients and families aware of quality HIV/AIDS resources

- Number of health library staff aware of quality HIV/AIDS resources

- Number of public/other library staff aware of quality HIV/AIDS resources

- Number of health professionals aware of quality HIV/AIDS resources

- Number of others aware of quality HIV/AIDS resources

- Number of not specified aware of quality HIV/AIDS resources

Quality HIV/AIDS Resource Utilization

- Number of general public utilizing quality HIV/AIDS resources

- Number of patients and families utilizing quality HIV/AIDS resources

- Number of health library staff utilizing quality HIV/AIDS resources

- Number of public/other library staff utilizing quality HIV/AIDS resources

- Number of health professionals utilizing quality HIV/AIDS resources

- Number of others utilizing quality HIV/AIDS resources

- Number of not specified utilizing quality HIV/AIDS resources

HIV-related Documents Utilization

- Number of general public utilizing HIV-related documents

- Number of patients and families utilizing HIV-related documents

- Number of health library staff utilizing HIV-related documents

- Number of public/other library staff utilizing HIV-related documents

- Number of health professionals utilizing HIV-related documents 


\section{- Number of others utilizing HIV-related documents \\ - Number of not specified utilizing HIV-related documents}

\section{Skills Development Related}

- Number of general public trained

- Number of patients and families trained

- Number of health library staff trained

- Number of public/other library staff trained

- Number of health professionals trained

- Number of others trained

- Number of not specified trained

Change in Awareness or Skill

- General public awareness - Pre-training: no awareness/low awareness, neutral, moderate/high awareness

- General public awareness - Post-training: no awareness/low awareness, neutral, moderate/high awareness

- Patient and family awareness - Pre-training: no awareness/low awareness, neutral, moderate/high awareness

- Patient and family awareness - Post-training: no awareness/low awareness, neutral, moderate/high awareness

- Health library staff awareness - Pre-training: no awareness/low awareness, neutral, moderate/high awareness

- Health library staff awareness - Post-training: no awareness/low awareness, neutral, moderate/high awareness

- Public/other library staff awareness - Pre-training: no awareness/low awareness, neutral, moderate/high awareness

- Public/other library staff awareness - Post-training: no awareness/low awareness, neutral, moderate/high awareness

- Health professionals awareness - Pre-training: no awareness/low awareness, neutral, moderate/high awareness

- Health professionals awareness - Post-training: no awareness/low awareness, neutral, moderate/high awareness

- Other awareness - Pre-training: no awareness/low awareness, neutral, moderate/high awareness

- Other awareness - Post-training: no awareness/low awareness, neutral, moderate/high awareness

- Not specified awareness - Pre-training: no awareness/low awareness, neutral, moderate/high awareness 
- Not specified awareness - Post-training: no awareness/low awareness, neutral, moderate/high awareness - General public ability - Pre-training: very incompetent/incompetent, neutral, competent/very competent

- General public ability - Post-training: very incompetent/incompetent, neutral, competent/very competent

- Patient and family ability - Pre-training: very incompetent/incompetent, neutral, competent/very competent

- Patient and family ability - Post-training: very incompetent/incompetent, neutral, competent/very competent

- Health library staff ability - Pre-training: very incompetent/incompetent, neutral, competent/very competent

- Health library staff ability - Post-training: very incompetent/incompetent, neutral, competent/very competent

- Public/other library staff ability - Pre-training: very incompetent/incompetent, neutral, competent/very competent

- Public/other library staff ability - Post-training: very incompetent/incompetent, neutral, competent/very competent

- Health professionals ability - Pre-training: very incompetent/incompetent, neutral, competent/very competent

- Health professionals ability - Post-training: very incompetent/incompetent, neutral, competent/very competent

- Other ability - Pre-training: very incompetent/incompetent, neutral, competent/very competent

- Other ability - Post-training: very incompetent/incompetent, neutral, competent/very competent

- Not specified ability - Pre-training: very incompetent/incompetent, neutral, competent/very competent

- Not specified ability - Post-training: very incompetent/incompetent, neutral, competent/very competent

\section{Satisfaction}

- General public satisfaction with training: very dissatisfied/dissatisfied, neutral, satisfied/very satisfied

- Patient and family satisfaction with training: very dissatisfied/dissatisfied, neutral, satisfied/very satisfied

- Health library staff satisfaction with training: very dissatisfied/dissatisfied, neutral, satisfied/very satisfied

- Public/other library staff satisfaction with training: very dissatisfied/dissatisfied, neutral, satisfied/very satisfied

- Health professionals satisfaction with training: very dissatisfied/dissatisfied, neutral, satisfied/very satisfied

- Other satisfaction with training: very dissatisfied/dissatisfied, neutral, satisfied/very satisfied

- Other satisfaction with training: very dissatisfied/dissatisfied, neutral, satisfied/very satisfied

- Unintended negative consequences (text)

- Unintended positive consequences (text) 


\section{Appendix D. Coding framework for awardee interviews}

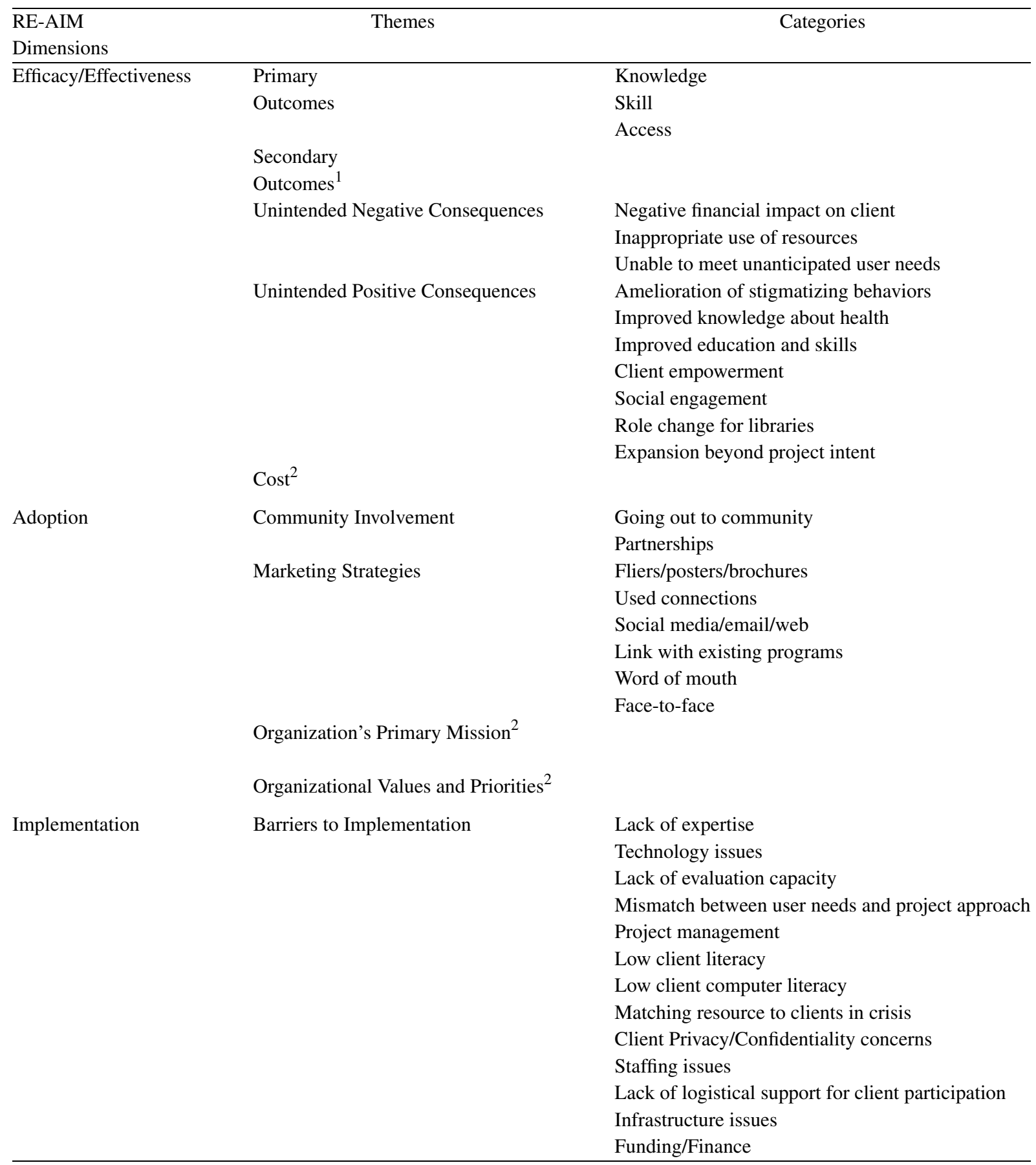

\footnotetext{
${ }^{1}$ No data coded into category.

${ }^{2}$ No categories - data coded at theme level.
} 


\begin{tabular}{ll}
\hline \multicolumn{1}{c}{$\begin{array}{l}\text { RE-AIM } \\
\text { Dimensions }\end{array}$} & \multicolumn{1}{c}{ Categories } \\
\hline Enabling (Facilitating) Factors & Built on existing efforts \\
& Staffing \\
Expertise & Resources tailored to user needs \\
& Safe environment \\
& Promoting/Marketing \\
& Technology \\
& Support for client participation \\
& Plan for evolving technologies \\
& Pre-submission planning \\
Lasting effects at individual level ${ }^{1}$ & Needs assessment \\
Sustainability of the program over time & Organizational power/position \\
& Information ecology/Big picture \\
& \\
& \\
Evolution of the program & Maintained with existing resources \\
& Maintained with new resources \\
& Maintained relationships
\end{tabular}

\section{Appendix E. Coding framework with example quotes from awardee interviews}

Efficacy/Effectiveness

\begin{tabular}{ll}
\hline Categories & \multicolumn{1}{c}{ Verbatim interview quotes } \\
\hline Theme: Primary Outcomes & $\begin{array}{l}\text { Well, it gave them more information about HIV. And there were; my clients have } \\
\text { all these myths about HIV, especially in the African American community. I had } \\
\text { a client that walked in here one day and she was HIV positive for ten years, or } \\
\text { had been HIV positive for ten years. And she was devastated; she was crying. } \\
\text { And I said what is wrong? She goes, I'm going to die. And I said what do you } \\
\text { mean you're going to die? Well, she thought that after ten years, she had been } \\
\text { told that after ten years with HIV, you die. } \\
\text { So people's computer skills increased. Their use of Medline Plus increased. And } \\
\text { they reported that they had changed some health behaviors. } \\
\text { I think one of the greatest successes of these awards is making electronic access } \\
\text { available where it often has not been available historically. }\end{array}$ \\
Skill & $\begin{array}{l}\text { And also, a lot of the people we work with are on disabilities. They're not } \\
\text { allowed to earn much more than, you know, a little bit of money. And then for } \\
\text { them the negative consequences are that they pay taxes on this money. And } \\
\text { they're expected to report it to disability. And if they don't do that, they get into } \\
\text { trouble. And that's happened because people didn't know. }\end{array}$ \\
\hline &
\end{tabular}




\begin{tabular}{ll}
\hline Categories & \multicolumn{1}{c}{ Verbatim interview quotes } \\
\hline Inappropriate use of resources & $\begin{array}{l}\text { We have had a couple members, for example, who spend a lot of time in the } \\
\text { resource room who act like it's their living room, and so there has been other } \\
\text { clients who have felt like, well, I don't want to go in there because I don't feel } \\
\text { like dealing with John ... had hard conversations with some of our clients to say } \\
\text { look, you know, you can't be here, you know, six hours a day. }\end{array}$ \\
$\begin{array}{l}\text { But when it's an anonymous person on YouTube, that model is really difficult. In } \\
\text { this instance, the gist was ... it opened up a whole set of questions that we were } \\
\text { not prepared to answer in terms of our service provision. }\end{array}$
\end{tabular}

Theme: Unintended Positive Consequences Amelioration of stigmatizing behaviors

So I was teaching one for seniors a couple weeks ago and this woman was very honest. And she said she keeps her HIV friends at arm's length ... a separate place for them. You know and all this like Stone Age stuff. And everybody in the class really jumped on her. I didn't say a thing. And people corrected it and we showed her, you know, evidence where that was disproven. And she actually left the session saying she has to change her own behavior.

Improved knowledge about health I think that actually we started to engage people looking at their health more holistically. I mean, of course, the focus of HIV and STI's and there are people paying attention to that. But they also began to have sort of a broader view about, well, your health impacts you definitively, and you need to have an understanding of what your risks are. Not only for HIV, but other things as well. So this would get into other conversations about services that people would need, for instance, mental health; which people don't really talk about too much, either in the Latino population or African American.

Improved education and skills

I've had folks who ended up applying and going to school because they learned how to use the internet to look for a program to help them pay for school.

Client empowerment

I would say a positive would be that people connected with each other that would've never connected with each other before. And they were actually using some of the information that they learned through the calls and through the website when they went to doctor's appointments. They actually stated that on some of the calls, so I'm like yes, cool! That's great.

Social engagement

Partly the good is the community, you know, the community connections, the people being ... people feeling like they have community. They are able to have safe place to go and access what they need.

Role change for libraries

I guess the best positive unintended is, I guess, librarians and non-librarians understanding the benefit of health literacy in the library setting.

Expansion beyond project intent

We ended up creating a whole other area of work that has now gone national, that is just amazing.

Theme: Cost

$\$ 60,000 \ldots$ I do think it could be used to seed money in order to launch something maybe larger for an organization.

\begin{tabular}{lll} 
& Adoption & \\
\hline Categories & Verbatim interview quotes \\
\hline
\end{tabular}

Theme: Organization's Primary Mission

So we just felt that it was a natural fit for us and what could we do, you know, since we're trying to look at literacy from a larger umbrella.

Theme: Community Involvement Going out into the community

And we found that the easiest way, as opposed to trying to bring them first into the library was for us to actually go out to their sites, and in that way ... you know, when they have their meetings.

Partnerships

And initially, we also had a partner with a survivor project, which is no longer in existence, but it was an agency that really focused on information for people living with HIV. 


\begin{tabular}{|c|c|}
\hline Categories & Verbatim interview quotes \\
\hline \multicolumn{2}{|l|}{ Theme: Marketing Strategies } \\
\hline Used connections & $\begin{array}{l}\ldots \text { and we used all of the connections we had with provider entities and our } \\
\text { consumer advisory panels which we had from the agency already, to create a } \\
\text { massive marketing campaign. We distributed information every possible way. }\end{array}$ \\
\hline Fliers/posters/brochures & $\begin{array}{l}600 \text { sort of posters go up within the mass transit system about our walk-in } \\
\text { services that are available. So, we do a lot to try to educate the public about the } \\
\text { availability of services. }\end{array}$ \\
\hline Social media/email/web & ... social media. So blogs and Twitter was the main way that I marketed”. \\
\hline Link with existing programs & $\begin{array}{l}\text { One of the mechanisms that we used was when we found that there was a group } \\
\text { that meets on a regular basis we would contact the leader of that group to see if } \\
\text { we could come in as a guest speaker and meet with the groups. So we kind of } \\
\text { found different ways to promote the program, but we don't have the funds for } \\
\text { TV, and the newspapers are just not as good anymore. }\end{array}$ \\
\hline Word of mouth & $\begin{array}{l}\text { Well, there was a lot of word of mouth at that time.... So our agency was the } \\
\text { first in New England and still the largest in New England and you know, so we } \\
\text { had resources to get the word out. }\end{array}$ \\
\hline Face-to-face & $\begin{array}{l}\text { We essentially have folks who will go out and actually do site visits to different } \\
\text { other providers, like to support groups and other areas where they can directly } \\
\text { promote the services and the facility, to communities. }\end{array}$ \\
\hline \multicolumn{2}{|r|}{ Implementation } \\
\hline Categories & Verbatim interview quotes \\
\hline
\end{tabular}

Theme: Barriers to Implementation Lack of expertise

Technology issues

Lack of evaluation capacity

Mismatch between user needs and project approach

Project management

Low client literacy

Low client computer literacy
And initially when we got funded, our resource room was really led by our IT, but our key staff are not, you know, our key people are not the most warm ... right, not the most patient, maybe not the most people skilled focused, you know, and that's not their job. They are computer people, right? And so, what happened was we would have some challenges with some of the soft skill, that our members really appreciate about the agency overall. So, what we were trying to figure out is a way to staff with volunteers, so actually brought in our hotline.

Mainly the people we were reaching at the time were rural, very rural some of them. And internet access sometimes was a problem. Some of them only had cell phones, which if you don't have an unlimited plan, it you know, would eat up your cell phone minutes if you were to join a webinar or a weekly call.

I think another challenge in all of these projects is the evaluation piece, which is what you're grappling with also, like what are the outcomes that are realistic and pertinent to NLM. We have here a lot of different outcomes we'd like to see and they're hard to measure.

And the other thing is that people's lives are such that trying to do something on a scheduled basis was somewhat of a challenge. You know the telephone conferences were actually at a set time on a set day.

So I think the management side of things is always the more challenging. It's a lot of effort organizing any kind of program ... you know that ... then just trying to keep momentum going.

Some of them cannot read. Some of them can barely write. Some of them the English is not their first language.

One of the major challenges that we face with the population that we were working with and are still working with is that a big number of them don't even know how to use a computer. So they don't have an email address or anything like that. So facing that challenge what we decided to have like basic skills computer classes. So we were teaching the Latina how to use the computer, what is the computer. 


\begin{tabular}{ll}
\hline Categories & \multicolumn{1}{c}{ Verbatim interview quotes } \\
\hline Matching resource to clients in crisis & $\begin{array}{l}\text { And I think also the fact that many people who would be seeking this } \\
\text { information, you know, have sort of multiple crises going on. I mean it's one } \\
\text { event, probably one event or a series of events that is bringing them to accessing } \\
\text { rape crisis services. }\end{array}$ \\
& $\begin{array}{l}\text { It was our own creation with social network because there were issues around } \\
\text { confidentiality related to using Facebook that we didn't anticipate initially. And } \\
\text { Client privacy/confidentiality concerns } \\
\text { so we created our own social networking page that still is up and running and } \\
\text { it's still active. }\end{array}$
\end{tabular}

Recruitment issues

Staffing issues

Lack of logistical support for client participation

We would get people that would call and inquire, but never actually make that next step. And we tried to troubleshoot a lot of that.

Staff turnover is a huge issue. Sometimes it's literally people moving between organizations, but I do think that it's high burnout working in this field and so people come and may stay for a few years and look for other work.

Because, again, we work with Latinas, and most of them are housewives or single parents, no income. And we're planning to ... I'm exploring now that it's summer, I'm exploring the possibility to entertain their kids so they will have more time for them to practice all the computer skills, and learn more, and so on and so forth.

Infrastructure issues

Funding/Finance

Theme: Enabling (Facilitating) Factors NLM Resources

You are going to laugh, the biggest challenge is you're all set, you're ready to go, you've got everything lined up you go to do a training and the power goes out.

So in this period when we've had a rapid decline in public funding, we've had the number of people living with the virus, has probably gone up 30-40\%.

And what I think they loved about it was that one of the sites within the National Library, one of the links is about medicine, where they can check what medications they're taking and all that. So that is something, and they can check that in Spanish. So they love that part.

Partnership

But I think more importantly the requests that were coming in from organizations that were doing the front line work were asking us to do ... to work more closely with us and how can we ... what do you recommend we have at our sites in terms of reading materials and how do we get people to come into the library. So if anything, that was really the key piece.

Project management

Built on existing efforts

You know, we have implementation plans, for example, all of our programs within a department. So, each program coordinator is responsible for you know, insuring that the implementation plan happens, or the work plan.

... because it layered into existing efforts, we were able to include it in a number of ways where you know the guide wouldn't have had any connectivity outside of just producing the guide, if it was done by a lot of other organizations because they just don't run those big programs. They don't have that reach.

Staffing

Expertise

Resources tailored to user needs That they really have to have internally the staff onboard.

We had two or three individuals at a time from the target population who could help the client navigate the system.

And that so therefore, they may not be thinking about when they fund the national entity that you can both have good local reach to the extent we were talking about earlier, how you personalize things, but also where a national entity can really help a national entity like NLM maybe connect more of the dots.

Safe environment

Our clients feel safe here. And once they come here, we try to communicate a very safe and warm environment here. And so, once they come here, they feel .... they don't feel judged. 


Categories
Promoting/Marketing
Technology
Support for client participation

Plan for evolving technologies

Pre-submission planning

Needs assessment

Organizational power/position

$\underline{\text { Information ecology/big picture }}$
Verbatim interview quotes

And then promoted it through a variety of links and then also did print copies at our exhibit booth and at different meetings, where we would be exhibiting for other reasons. So, we were able to really advertise by putting it out in so many venues that where NLM didn't have to buy an exhibit booth, for example, where we were already going to be, or didn't have to buy a banner on a website because we already were partnered with other organizations who could list it. We had computers in publically accessible areas.

We found that we have what we call Friday night dinner night. That means we have a meeting come to the library and ... especially for those who have kids, we have dinner at the library and then we also have a program through the children's librarian at the library so that the adults can have the information that they need on the subject matter.

Everybody has text. I have clients that hardly know how to read, but they'll text me.

Yes, because that's the only way to really get the buy-in at the very beginning ... That four-week assessment will tell you whether or not you're really able to carry it out, you know, do people have too much on their plate, looking at what the guidelines may be, you know, how onerous is the reporting going to be, who's going to take on what task, who's going to be responsible.

The one thing that I would say is that really know the community and know the ... when you do the needs assessment, it needs to be as detailed and thorough as possible.

And I handle all of the public funding and so I report directly to the chief operating officer who reports to the CEO. So that allows me to then work on an even level amongst programs and marketing and legal and finance.

I think having a bigger picture where this work is placed is helpful to people.

Maintenance

Categories
Theme: Sustainability of the program over time
Maintained with existing resources

Maintained with existing resources

It's one of those programs that because funding ended, the program didn't go away. The program is still as viable, you know, maybe we have more limited resources, but it just has really been a real good addition for our agencies list of resources that we have available for our clients.

Maintained with new resources

I feel like this grant actually was the impetus for a series of other grants that we ended up being able to get both through the National Library of Medicine and through some other sources as well because we sort of invested in creating the system in this class so then we could say we have the system in this class and we're ready to go.

Maintained relationships

I keep in touch with the community of CBOs that I've worked with for a while after the end of each of these. And I certainly make myself available as a resource to our project participants.

Not maintained

When the project ended, it was decided by the management at the Foundation, if I can call them that, that we would not continue to search out funding, since it wasn't a priority.

Theme: Evolution of the program Content updates

... we've so rebranded since that time, so this is all our old look and everything. So, we would've had to redo it. And I think that things have changed so much around HIV, we would have to redo the whole brochure.

Mobile devices
We're definitely exploring mobile devices and how to best provide materials on mobile devices. So it's definitely something that we're very interested in. 


\section{References}

[1] S. Bakken and C.M. Ruland, Translating clinical informatics interventions into routine clinical care: How can the RE-AIM framework help?, J. Am. Med. Inform. Assoc. 16(6) (2009), 889-897.

[2] C.M. Burroughs and F.B. Wood, Measuring the Difference: Guide to Planning and Evaluating Health Information Outreach, National Network of Libraries of Medicine, National Library of Medicine, Bethesda, MD, USA, 2007, available at: http://nnlm.gov/evaluation/guide/.

[3] M. Duggan and J. Brenner, The demographics of social media users - 2012 (Internet). Pew Internet \& American Life Project, 2013 February 14 (cited 2013 July 22), available at: http://www.pewinternet.org/Reports/2013/Social-mediausers.aspx.5.

[4] A.S. Fauci and G.K. Folkers, Toward an AIDS-free generation toward an AIDS-free generation, JAMA 308(4) (2012), 343-344.

[5] S. Flicker, M. Wilson, R. Travers et al., Community-based research in AIDS-service organizations: What helps and what doesn't?, AIDS Care 21(1) (2009), 94-102.

[6] S. Fox and M. Duggan, Mobile health (Internet). Pew Internet \& American Life Project, 2012 November 8 (cited 2013 July 22), available at: http://www.pewinternet.org/Reports/2012/Mobile-Health.aspx.

[7] R.E. Glasgow, L.M. Klesges, D.A. Dzewaltowski, P.A. Estabrooks and T.M. Vogt, Evaluating the impact of health promotion programs: Using the RE-AIM framework to form summary measures for decision making involving complex issues, Health Educ. Res. 21(5) (2006), 688-694.

[8] R.E. Glasgow, H.G. McKay, J.D. Piette and K.D. Reynolds, The RE-AIM framework for evaluating interventions: What can it tell us about approaches to chronic illness management?, Patient Educ. Couns. 44(2) (2001), 119-127.

[9] K.J. Horvath, G.P. Danilenko, M.L. Williams et al., Technology use and reasons to participate in social networking health websites among people living with HIV in the US, AIDS Behav. 16(4) (2012), 900-910.

[10] Information services for HIV/AIDS: Recommendations to the NIH, Report No. 94-3730, Department of Health and Human Services, National Institutes of Health, Bethesda, MD, USA, 1994.

[11] S.C. Kalichman, E.G. Benotsch, L. Weinhardt, J. Austin, W. Luke and C. Cherry, Health-related Internet use, coping, social support, and health indicators in people living with HIV/AIDS: preliminary results from a community survey, Health Psychol. 22(1) (2003), 111-116.

[12] S.C. Kalichman, D. Cain, C. Cherry, H. Pope, L. Eaton and M.O. Kalichman, Internet use among people living with HIV/AIDS: Coping and health-related correlates, AIDS Patient Care STDs 19(7) (2005), 439-448.

[13] S.C. Kalichman, L. Weinhardt, E. Benotsch, K. DiFonzo, W. Luke and J. Austin, Internet access and internet use for health information among people living with HIV-AIDS, Patient Educ. Couns. 46(2) (2002), 109-116.

[14] J.A. Kelly, A.M. Somlai, W.J. DiFranceisco et al., Bridging the gap between the science and service of HIV prevention: Transferring effective research-based HIV prevention interventions to community AIDS service providers, American J. Pub. Health 90(7) (2000), 1082.

[15] D.P. Lorence, H. Park and S. Fox, Racial disparities in health information access: Resilience of the digital divide, J. Medical Syst. 30(4) (2006), 241-249.

[16] J.C. Magee, L. Bigelow, S. Dehaan and B.S. Mustanski, Sexual health information seeking online a mixed-methods study among lesbian, gay, bisexual, and transgender young people, Health Educ. Behav. 39(3) (2012), 276-289.

[17] NLM Board of Regents, Improving health professionals' access to information, Department of Health and Human Services, National Institutes of Health, Bethesda, MD, USA, 1989.

[18] NLM Board of Regents, Charting a course for the 21st century: NLM's Long Range Plan 2006-2016, Department of Health and Human Services. National Institutes of Health, Bethesda, MD, USA, 2006 (cited 2013 July 22), available at: http://www.nlm.nih.gov/pubs/plan/.

[19] L. Samal, S. Saha, G. Chander et al., Internet health information seeking behavior and antiretroviral adherence in persons living with HIV/AIDS, AIDS Patient Care STDs 5(7) (2011), 445-449.

[20] J.D. Schulden, B. Song, A. Barros et al., Rapid HIV testing in transgender communities by community-based organizations in three cities, Public Health Rep. 123(3) (2008), 101.

[21] R.K. Shrestha, H.A. Clark, S.L. Sansom et al., Cost-effectiveness of finding new HIV diagnoses using rapid HIV testing in community-based organizations, Public Health Rep. 123(3) (2008), 94.

[22] W.M. Valenti, Impact of changing demographics of HIV/AIDS on role of primary care, The AIDS Reader 18(8) (2008), $402-404,412$. 